\title{
ARBITRAGEM ENVOLVENDO O ESTADO NO DIREITO BRASILEIRO
}

\author{
SUZANA DOMINGUES MEDEIROS*
}

I - Introdução; II - Arbitrabilidade Subjetiva e Objetiva na Legislação Brasileira; III - Princípio da Legalidade como Pressuposto da Arbitrabilidade Subjetiva; IV - Evolução da Legislação Pertinente; $V$ - Arbitrabilidade Objetiva: Direitos Disponíveis $x$ Direitos Indisponiveis; VI- Particularidades das Empresas Públicas e Sociedades de Economia Mista; VII - Posição da Jurisprudência; VIII - Conclusão

\section{I- Introdução}

A análise da possível submissão à arbitragem deve necessariamente passar pelo exame da arbitrabilidade, que comporta duas etapas: a arbitrabilidade subjetiva e a arbitrabilidade objetiva. A arbitrabilidade subjetiva determina quem pode se submeter à arbitragem, ao passo que a arbitrabilidade objetiva estabelece quais matérias podem ser resolvidas por juízo arbitral, estando relacionada ao objeto da controvérsia.

Assim, para se verificar se, à luz do Direito Brasileiro, o Estado e entes da Administração Pública (direta e indireta) podem se submeter à arbitragem é preciso analisar, primeiramente, se estes passam pelo crivo da arbitrabilidade subjetiva. Somente após ultrapassada essa etapa, examina-se a arbitrabilidade objetiva, perquirindo-se se o objeto da controvérsia pode ser resolvido por arbitragem, matéria atinente à disponibilidade de direitos.

O presente estudo estará restrito à análise do tema na legislação, doutrina $\mathrm{e}$ jurisprudência brasileiras. Não analisaremos a possibilidade de o Estado brasileiro se submeter à arbitragem no exterior, questão que envolve inúmeros desdobramentos,

* Mestranda em Direito Internacional e Integração Econômica da UERJ e bolsista do Programa ANP-UERJ. A autora agradece a inestimável colaboração da Professora Carmen Tiburcio para a elaboração desse artigo.

R. Dir. Adm.,

Rio de Janeiro, 233: 71-101,

Jul./Set. 2003 
como por exemplo, a imunidade de jurisdição, ou melhor, a imunidade arbitral.' Também não trataremos do tema no Direito Comparado.

\title{
II - Arbitrabilidade subjetiva e objetiva na legislação brasileira
}

Jacob Dolinger e Carmen Tiburcio definem com precisão o significado da arbitrabilidade:

\begin{abstract}
"Mesmo se partindo da premissa que a jurisdição - aplicação da lei ao caso concreto - é uma das funções do Estado, admite-se que as partes possam decidir submeter a solução de seus litigios à arbitragem ao invés de à jurisdiçāo estatal. O Estado conserva, todavia, o poder de impedir que determinadas questões sejam dirimidas pela via da arbitragem, resultando no estabelecimento da regra da competência exclusiva da jurisdição estatal no que se refere a determinadas controvérsias. Nesse caso, diz-se que o litígio não é passível de ser resolvido por arbitragem, ou melhor, não é arbitrável. Dessa forma, a arbitrabilidade é uma condição de validade da convenção arbitral e conseqüentemente da competência dos árbitros."
\end{abstract}

A legislação brasileira, no tocante à arbitrabilidade subjetiva, sempre enunciou que podem se valer da arbitragem as pessoas capazes. Além disso, tradicionalmente vinculava-se a arbitragem à transação, ao se estabelecer que somente poderiam celebrar compromisso aqueles que tinham poderes para transigir. ${ }^{3}$

A Lei de Arbitragem (Lei $n^{\circ} 9.307 / 96$ ) logo no art. $1^{\circ}$ previu que " 'as pessoas capazes de contratar poderão valer-se da arbitragem' para dirimir litígios relativos

1 O tema da arbitragem envolvendo o Estado, inclusive no tocante à arbitragem internacional, foi exaustivamente tratado por Jacob Dolinger e Carmen Tiburcio no livro "Arbitragem Comercial Internacional", com a análise da doutrina, jurisprudência arbitral e estatal e da legislação no direito interno e no dircito comparado. (Arbitragem Envolvendo o Estado e Entes da Administração Pública. In: Direito Internacional Privado - Parte Especial: Arbitragem Comercial Internacional, Rio de Janeiro: Renovar, 2003).

2 Arbitrabilidade. In: Direito Imernacional Prisado - Parte Especial: Arbitragem Comercial Internacional, Rio de Janeiro: Renovar, 2003.

3 O Decreto $n^{\circ} 3.900$ de 1867 determinava em seu art. $4^{\circ}$ que "podem fazer compromisso todos os que podem transigir". O Regulamento 737 de 1850 possuía a mesma regra no art. 414. No Código Comercial de 1850 não há disposição expressa sobre a arbitrabilidade subjetiva. O Código Civil de 1916, no art. 1.037, estabelecia que "as pessoas capazes de contratar poderão, em qualquer tempo, louvar-se, mediante compromisso escrito, em árbitros, que lhes resolvam as pendências judiciais ou extrajudiciais", e o art. 1.048 previa que "ao compromisso se aplicará, quanto possivel. o disposto acerca da trantsaçāo (arts. 1.025 a l.036)". Por fim. o Código de Processo Civil de 1973 estabeleceu no art. 1.072 que "as pessoas capazes de contratar poderão louvar-se, mediante compromisso escrito, em árbitros que lhes resolvam as pendências judiciais ou extrajudiciais de qualquer valor, concernentes a direitos patrimoniais, sobre os quais a lei admita transação". Logicamente a expressāo "pessoas capazes" engloba as pessoas físicas e jurídicas. 
a direitos patrimoniais disponíveis" (grifo acrescentado). Na mesma linha, o art. 851 do Novo Código Civil (Lei $n^{\circ}$ 10.406/02) dispõe que "é admitido compromisso, judicial ou extrajudicial, para resolver litígios entre pessoas que podem contratar".

A arbitrabilidade objetiva sempre esteve restrita às questões passíveis de transação, ou seja, relativas a direitos patrimoniais disponíveis. ${ }^{4}$ A Lei ${ }^{\circ} 9.307 / 96$ restringiu o seu âmbito de aplicação, prevendo que " as pessoas capazes de contratar poderão valer-se da 'arbitragem para dirimir litígios relativos a direitos patrimoniais disponiveis'" (grifo acrescentado). No tocante aos direitos indisponíveis, a lei dispôs expressamente que "sobrevindo no curso da arbitragem controvérsia acerca de direitos indisponíveis e verificando-se que de sua existência, ou não, dependerá o julgamento, o árbitro ou o tribunal remeterá as partes à autoridade competente do Poder Judiciário, suspendendo o procedimento arbitral" (art. 25).

$\mathrm{O}$ art. 852 do Novo Código Civil prevê que é vedado compromisso para solução de questões de estado, de direito pessoal, de família e de outras que não tenham caráter estritamente patrimonial. O Novo Código não adotou, portanto, a fórmula genérica "direitos patrimoniais disponíveis", mas preferiu enumerar as questões insuscetíveis de solução pela via arbitral. $O$ art. 853 faz expressa remissão à lei especial, ou seja, à Lei de Arbitragem, devendo-se aplicar, portanto, o seu art. $1^{\circ}$ combinado com as restrições enumeradas pelo art. 852 do Novo Código.

Verifica-se que a legislação brasileira sobre arbitragem não dispôs acerca da capacidade de o Estado brasileiro se submeter à arbitragem. A omissão pode ser justificada pelo fato da legislação citada pertencer ao direito privado. Deve-se, portanto, analisar as normas de direito público sobre o tema.

\section{III - Princípio da legalidade como pressuposto da arbitrabilidade subjetiva}

Nos termos do art. 37 da Constituição Federal de 1988, a Administração Pública direta e indireta de qualquer dos Poderes da União, dos Estados, do Distrito Federal e dos Municípios, obedecerá ao princípio da legalidade. Significa, portanto, que a

4 No Código Comercial não havia disposição expressa sobre a arbitrabilidade objetiva, mas, como se sabe, esse diploma previa a arbitragem obrigatória para causas tipicamente de natureza comercial, quais sejam, questões envolvendo contratos de locaçāo mercantil (art. 245), matéria societária (art. 294), casos de naufrágios (art. 739), avarias (art. 783) e quebras (art. 846). Do mesmo modo, o Código Civil de 1916 não apresentava regra expressa, prevendo somente no art. 1.048 que ao compromisso se aplicará, quanto possível, o disposto acerca da transaçāo. Dentre as normas referentes à transação, o art. 1.035 estabelecia que "só quanto a direitos patrimoniais de caráter privado se permite a transação". O art. 1.072 do Código de Processo Civil de 1973, conforme transcrito na nota acima, restringia a possibilidade de celebração do compromisso a pendências judiciais ou extrajudiciais de qualquer valor, concernentes a direitos patrimoniais sobre os quais a lei admitisse transação. Note-se que havia previsão expressa no CPC de 1973 sobre a incompetência do árbitro para decidir sobre questōes relativas a direitos sobre os quais a lei não admite transação (art. 1.094). 
atuação da Administração Pública deve estar sempre balizada na lei. A Administração Pública não tem vontade própria, a sua vontade é a lei.

O princípio da legalidade possui, assim, dupla função: a Administração, além de só poder fazer aquilo que não é vedado por lei, também só pode fazer o que é expressamente permitido por lei. Sobre o princípio da legalidade,,$^{5}$ vale transcrever os ensinamentos de Hely Lopes Meirelles e Celso Antônio Bandeira de Mello, respectivamente:

"O administrador público está, em toda a sua atividade funcional, sujeito aos mandamentos da lei è às exigências do bem comum, e deles não se pode afastar ou desviar; sob pena de praticar ato inválido e expor-se a responsabilidade disciplinar, civil ou criminal, conforme o caso. (...) Na Administração Pública não há liberdade nem vontade pessoal. Enquanto na administração particular é lícito fazer tudo que a lei não proíbe, na Administração Pública só é permitido fazer o que a lei autoriza." ${ }^{6}$

"Este é o princípio capital para a configuração do regime jurídico-administrativo. Justifica-se, pois, que seja tratado - como o será - com alguma extensão e detença. (...) Em suma: a consagração da idéia de que a Administração Pública só pode ser exercida na conformidade da lei e que, de conseguinte, a atividade administrativa é atividade sublegal, infralegal, consistente na expedição de comandos complementares à lei. (...) 'O princípio da legalidade, no Brasil, significa que a Administração nada pode fazer senão o que a lei determina. Ao contrário dos particulares, os quais podem fazer tudo o que a lei não proíbe, a Administração só pode fazer o que a lei antecipadamente autorize'." 7 (grifo acrescentado)

Conclui-se que, sob a ótica do princípio da legalidade tal como definido pelos autores citados, a Administração Pública, na ausência de lei autorizativa, não pode celebrar contrato contendo cláusula arbitral. Porém, indaga-se se a lei genérica autorizando a submissão à arbitragem resolveria a questão ou se ainda restaria a barreira da arbitrabilidade objetiva. Vale dizer, em havendo lei autorizando a submissão à arbitragem, ainda seria necessário verificar em cada hipótese a natureza dos direitos envolvidos na atuação da Administração Pública - se disponíveis ou indisponíveis - , para saber se eles se coadunam com a utilização da arbitragem?

5 Vide, ainda, BARROSO, Luís Roberto. Sociedade de Economia Mista Prestadora de Serviço Público. Cláusula Arbitral Inserida em Contrato Administrativo scm Prévia Autorização Legal. Invalidade. In: Temas de Direito Constitucional, Tomo II, Rio de Janeiro: Renovar, 2003, pp. 615-616. O autor traz interessante comentário acerca do princípio da eficiência e da sua relação com o princípio da legalidade no que concerne à arbitragem.

6 MEIRELLES, Hely Lopes. Direito Administrativo Brasileiro, São Paulo: Malheiros, 1993, p. 82.

7 MELLo, Celso Antônio Bandeira de. Curso de Direito Administrativo, $13^{\circ}$ ed., São Paulo: Malheiros, 2001, pp. 71, 75 e 76. 
Dada a importância do princípio da legalidade. que deve nortear os atos da Administração, é importante analisar a evolução da questão à luz da legislação brasileira de direito público.

Primeiramente, podemos citar a regra contida no $\S 1^{\circ}$, do art. 775 , do Decreto $\mathrm{n}^{\circ} 15.783$, de 1922 (regulamentou o Código de Contabilidade da União), que previa a obrigatoriedade nos contratos administrativos de cláusula declarando competente o foro nacional brasileiro. Vale observar a redação do $\S 1^{\circ}$, do art. 775 :

"A estipulação dos contratos administrativos compreende cláusulas essenciais e cláusulas acessórias. São cláusulas essenciais e como tais não podem ser omitidas em contrato algum, sob pena de nulidade:

e) nos contratos com pessoas naturais ou jurídicas domiciliadas no estrangeiro, 'a cláusula que declara competente oforo nacional brasileiro', para dirimir quaisquer questões originadas dos mesmos contratos." (grifo acrescentado)

A Lei $n^{\circ} 5.662$, de 1971, que transformou o Banco Nacional de Desenvolvimento Econômico em empresa pública, autorizou-o, em seu art. $5^{\circ}$, a realizar no exterior as operações bancárias necessárias ao desenvolvimento nacional, autorizando igualmente a aceitar as cláusulas usuais em contratos internacionais, entre elas o arbitramento. Segundo observa Jacob Dolinger, esse dispositivo foi o precursor do art. 11, do Decreto-lei $n^{\circ} 1.312 / 74$, que estendeu essa permissão ao Tesouro Nacional. ${ }^{8}$

Assim, o Decreto-lei n ${ }^{\circ} 1.312$, de 1974, que autorizava o Poder Executivo a dar garantia do Tesouro Nacional a operações de créditos obtidos no exterior e a contratar créditos em moeda estrangeira, determinou que o Tesouro Nacional estava autorizado a aceitar as cláusulas e condições usuais nas operações com organismos financiadores internacionais, "sendo válido o compromisso geral e antecipado de dirimir por arbitramento todas as dúvidas e controvérsias derivadas dos respectivos contratos". Ou seja, o legislador, consciente das exigências dos organismos financiadores internacionais no tocante à segurança dos seus investimentos, autorizou a celebração de cláusula compromissória.

O Decreto-lei $n^{\circ} 2.300$, de 1986, diploma legal que disciplinava as licitações e contratos da Administração, quando da sua promulgação, previa a obrigatoriedade de cláusula que declarasse competente o foro do Distrito Federal para dirimir qualquer questão contratual (parágrafo único do art. 45), vedando expressamente a utilização do juízo arbitral. ${ }^{9}$ Contudo, menos de um ano após o início de sua vigência,

8 DOLINGER, Jacob. A Imunidade Jurisdicional dos Estados. Revista Forense 277/53-80, p. 78.

9 Redação original do parágrafo único do art. 45: "Nos contratos com pessoas físicas ou jurídicas domiciliadas no estrangeiro deverá constar, necessariamente, cláusula que declare competente o foro do Distrito Federal para dirimir qualquer questão contratual, vedada a instituição de juizo arbitral." 
foi promulgado o Decreto-lei $n^{\circ} 2.348$, de 1987, que alterou diversos artigos do Decreto-lei $\mathrm{n}^{\circ} 2.300 / 86$, dentre eles o parágrafo único do art. 45 , passando a prever a possibilidade de utilização de juízo arbitral em algumas hipóteses de licitação internacional previstas no $\$ 13$ do artigo $25^{10}$, in verbis:

"Art. 45. Parágrafo único - Nos contratos celebrados pela União Federal ou suas autarquias, com pessoas físicas ou juridicas domiciliadas no estrangeiro, deverá constar, necessariamente, cláusula que declare competente o foro do Distrito Federal para dirimir qualquer questão contratual, salvo o disposto no $\$ 13$ do artigo 25, permitido nesse caso o juizo arbitral'." (grifo acrescentado)

Jacob Dolinger, ao interpretar esse dispositivo, afirma que ficou claro que somente nas hipóteses discriminadas é que o contrato poderá deixar de prever o foro do Distrito Federal, mantida assim a regra geral da imunidade jurisdicional do Estado brasileiro. "O que não ficou claro, a nosso ver. é se na hipótese do $\S 13$ do art. 25 estava permitido somente o juizo arbitral ou também a eleição de foro estrangeiro. A par essa controvérsia, observe-se que a alteração introduzida pelo Decreto-lei $n^{\circ}$ 2.348 não era satisfatória, pois permitia a adoção da arbitragem apenas em hipóteses muito restritas de licitação internacional.

É importante observar que o referido dispositivo somente previa a obrigatoriedade do foro do DF para os contratos celebrados com pessoas físicas ou juridicas domiciliadas no exterior. Todavia, não nos parece que possamos interpretar tal dispositivo a contrario sensu, no sentido de considerar autorizada a arbitragem para os contratos com pessoas físicas ou jurídicas domiciliadas no País. Ora, não faria sentido o legislador vedar a adoção da arbitragem para os contratos celebrados com sociedades estrangeiras - onde com mais razão se justificaria a sua adoção - e permitir a sua utilização nos contratos com sociedades brasileiras. Além disso, a autorização para a utilização da arbitragem era prevista em casos excepcionalíssimos, devendo toda exceção ser interpretada restritivamente.

O Decreto-lei $n^{\circ} 2.300$ foi revogado expressamente pela Lei $n^{\circ} 8.666 / 93^{12}$, que passou a reger as licitações e contratos da Administração. Note-se, contudo, que a nova Lei possui um âmbito de aplicação bem mais amplo do que o Decreto-lei $n^{\circ}$ $2.300^{13}$, pois se aplica não somente à Administração Pública direta e indireta, mas

10 Confira-se a redação do $\$ 13$, do art. 25 : “O disposto no $\$ 2^{\circ}$ do artigo $3^{\circ}$, no $\$ 10$ do artigo 25, no $\$ l^{\circ}$ do artigo 26 e no parágrafo tínico do artigo 45, não se aplica às concorrências internacionais, para a aquisição de bens ou serviços cujo pagamento seja feito com o produto de financiamento concedido por organismo internacional, de que o Brasil faça parte, nem nos casos de contratação com empresa estrangeira, para a compra de equipamentos fabricados e entregues no exterior. desde que para este caso tenha havido prévia autorização do Presidente da República."

11 DOLINGER, Jacob. A Dívida Externa Brasileira: Solução pela Via Arbitral, Rio de Janeiro: Nova Fronteira, 1988, p. 79.

12 Art. 126 da Lei $n^{\circ} 8.666 / 93$.

13 O escopo do Decreto-lei $n^{\circ} 2.300$ era bem mais restrito, limitando-se a reger as licitaçōes e 
também às entidades controladas, direta ou indiretamente, pela União, Estados, Distrito Federal e Municípios. ${ }^{14}$ A Lei $n^{\circ} 8.666 / 93$ também possui maior amplitude quanto aos tipos de contrato celebrados pela Administração, aplicando-se inclusive a contratos de locação (art. $1^{\circ}$ ).

Com relação à possibilidade de utilização da arbitragem, o art. $55, \S 2^{\circ}$, da Lei $n^{\circ} 8.666 / 93$ trouxe regra imprecisa e lacunosa que acabou por gerar incerteza com relação à possibilidade de utilização da arbitragem nos contratos da Administração, in verbis:

\footnotetext{
"Nos contratos celebrados pela Administração Pública com pessoas físicas ou jurídicas, inclusive aquelas domiciliadas no estrangeiro, deverá constar necessariamente cláusula que declare competente oforo da sede da Administração para dirimir qualquer questão contratual, salvo o disposto no § 6 do art. 32 desta Lei." 15
}

Sem dúvida a regra geral era a proibição da escolha de foro estrangeiro. ${ }^{16}$ Note-se que, diversamente da regra do Decreto-lei $n^{\circ} 2.300$, a redação é clara ao

contratos administrativos pertinentes a obras, serviços, compras e alienações, no âmbito da Administração Federal centralizada e autárquica, nos termos do seu art. $1^{\circ}$.

14 Art. $1^{\circ}$ da Lei $n^{\circ} 8.666 / 93$ - "Esta Lei estabelece normas gerais sobre licitaçōes e contratos administrativos pertinentes a obras, serviços, inclusive de publicidade, compras, alienaçōes $e$ locaçōes no âmbito dos Poderes da União, dos Estados, do Distrito Federal e dos Municípios. Parágrafo único - Subordinam-se ao regime desta Lei, além dos órgãos da administraçâo direta, os fundos especiais, autarquias, as fundaçōes públicas, as empresas públicas, as sociedades de economia mista e demais entidades controladas direta e indiretamente pela União, Estados, Distrito Federal e Municipios."

15 Art. $32, \S 6^{\circ}-" O$ disposto no $\S 4^{\circ}$ deste artigo, no $\S 1^{\circ}$ do art. 33 e no $\S 2^{\circ}$ do art. 55 , näo se aplica às licitaçōes internacionais para a aquisição de bens e serviços cujo pagamento seja feito com o produto de financiamento concedido por organisno financeiro internacional de que o Brasil faça parte, ou por agência estrangeira de cooperação, nem aos casos de contratação com empresa estrangeira, para a conpra de equipamentos fabricados e entregues no exterior, desde que para este caso tenha havido prévia autorização do Chefe do Poder Executivo, nem nos casos de aquisição de bens e serviços realizada por unidades administrativas com sede no exterior." (grifo acrescentado)

16 A vedação à escolha de foro estrangeiro foi enfatizada por Carmen Tiburcio em comentário ao contrato celebrado entre o Município do Rio de Janeiro, pessoa jurídica de direito público interno, e a Fundação Guggenheim, pessoa jurídica estrangeira, para a instalação do museu Guggenheim carioca, com clá: isula elegendo o foro de Nova York como o competente para julgar eventuais litígios oriundos do contrato: "O tema é bastante controverso, sobretudo em função do atual art. 55 , $\$ 2^{\circ}$, da Lei 8.666/93, sobre licitações e contratos administrativos, segundo o qual a cláusula que elege o foro da sede da Administração é essencial em todo contrato firmado por esta. Assim. há na Lei uma regra imperativa que estabelece como fundamental, em tais contratos, a eleição de foro do lugar onde está sediada a Administração, o que naturalmente impede a escolha de outro foro que não aquele indicado pela Lei. Assim, no caso concreto, o contrato deveria, por imposiçāo legal, determinar o foro da cidade do Rio de Janeiro como o competente para apreciar as questöes relativas ao mencionado negócio. Não se diga que tal dispositivo só se aplica aos contratos de 
estender também a obrigatoriedade do foro da sede da Administração aos contratos celebrados com pessoas físicas e jurídicas domiciliadas no Brasil. Todavia, a retirada da menção expressa ao juízo arbitral para algumas hipóteses de licitação internacional (as hipóteses previstas no $\S 6^{\circ}$, do art. 32, são basicamente as mesmas do $\S 13$, do art. 25, do Decreto-lei $n^{\circ} 2.300$ ) poderia gerar dúvidas quanto à finalidade dessa omissão. Ou seja, nas hipóteses excepcionais do $\S 6^{\circ}$ do art. 32 estava permitida a eleição de foro estrangeiro e a arbitragem ou somente a eleição de foro estrangeiro, eis que a lei não mencionou a arbitragem em momento algum. Mauro Roberto Gomes de Mattos entende continuar sendo possível a utilização da arbitragem: "A Lei de Licitaçōes (Lei $n^{\circ} 8.666 / 93$ ) também se integra a este quadro, para os contratos administrativos que envolvam financiamentos internacionais, em que é permitida a estipulação da instância arbitral (art. $32, \S 6^{\circ}$ ) como meio legal para a solução de controvérsias surgidas quando do cumprimento e interpretação do contrato". ${ }^{17}$

A principal questão está, porém, na primeira parte do dispositivo, que prevê a obrigatoriedade de cláusula declarando competente o foro da sede da Administração. Luís Roberto Barroso adota o entendimento de que este dispositivo constitui um obstáculo à utilização da arbitragem:

"A Lei $n^{\circ} 8.666 / 93$ estabelece, em seu art. $55, \S 2^{\circ}$, a obrigatoriedade de se incluir, nos contratos firmados pela Administração, cláusula que declare competente o foro da sede da Administração para dirimir qualquer questão contratual. Assim, a referida lei não apenas não autoriza a arbitragem, como veda, logicamente, sua previsão." 18

Registre-se que o $\S 2^{\circ}$, do art. 55 , da Lei $n^{\circ} 8.666 / 93$, representou um retrocesso, na medida em que criou um obstáculo à utilização da arbitragem em praticamente todos os contratos celebrados pela Administração Pública. Isto porque o $\S 3^{\circ}$, do art. 62, da Lei $n^{\circ} 8.666 / 93$, ampliou a incidência do art. 55 até mesmo aos contratos da Administração cujo conteúdo seja regido, predominantemente, pelo direito privado. ${ }^{19}$

direito público, pois a Lei também é clara ao estabelecer que o art. $55, \S 2^{\circ}$, também se aplica aos contratos de direto privado celebrados pela Administração (art. 62, $\$ 3^{\circ}$, I, da Lei 8.666/93)." (Gazeta Mercantil de 21.05.03, Caderno Legal e Jurisprudência, p. 2).

17 MATTOS, Mauro Roberto Gomes de. Contrato Administrativo e a Lei de Arbitragem. Revista de Direito Administrativo 223/122.

18 BARROSO, Luís Roberto. Sociedade de Economia Mista Prestadora de Serviço Público. Cláuisula Arbitral Inserida em Contrato Administrativo sem Prévia Autorização Legal. Invalidade. In: Temas de Direito Constitucional, Tomo II, Rio de Janeiro: Renovar, 2003, p. 636.

19 Art. $62, \S 3^{\circ}$ - "Aplica-se o disposto nos arts. 55 e 58 a 61 desta Lei e demais normas gerais, no que couber:

I - Aos contratos de seguro, de financiamento, de locação em que o Poder Público seja locatário, "e os demais cujo conteúdo seja regido, predominantemente. por norma de direito privado".

II - Aos contratos em que a Administração for parte como usuária de serviço público." (grifo acrescentado) 
Interpreta-se esse dispositivo como uma intenção do legislador de publicizar todos os contratos da Administração ${ }^{20} \mathrm{e}$, nesse sentido, toda a discussão acerca da distinção entre contratos administrativos e contratos privados da Administração para efeitos de possibilitar a utilização da arbitragem perderia, a princípio, o sentido.

Cabe aqui registrar que, não obstante a previsão do $\S 2^{\circ}$ do art. 55 e do $\S 3^{\circ}$ do art. 62, alguns autores defendem a possibilidade de utilização da arbitragem nos contratos administrativos com base no art. 54 da Lei $n^{\circ} 8.666 / 93$, que dispõe que "os contratos administrativos de que trata esta lei regulam-se pelas suas cláusulas e pelos preceitos de direito público, aplicando-se, supletivamente, os princípios da teoria geral dos contratos e as disposiçóes de direito privado". Por ser a arbitragem um instituto de direito privado, estaria permitida a sua utilização com base nesse artigo. Essa é a posição defendida por Adilson Abreu Dallari, ao comentar a decisão do Tribunal de Contas da União que considerou inválida a cláusula arbitral do Edital relativo à concessão para a exploração da ponte Rio-Niterói em razão da inexistência de fundamento legal, e por Arnoldo Wald, conforme se verifica dos trechos abaixo, respectivamente:

"Tal entendimento, quando estabelecido, já estava equivocado, pois efetivamente já havia naquela ocasião fundamento legal para a arbitragem, embora não explícito.

'Com efeito, o art. 54 da Lei $n^{\circ} 8.666$, de 21.6.93, assim dispöe': (...).

Isso significa que poder-se-ia ter aplicado, supletivamente e no que coubesse, o disposto nos artigos 1.037 a 1.048 do Código Civil (que trata do compromisso, ao dispor sobre o Direito das Obrigações), e nos artigos 1.072 a 1.102 do Código de Processo Civil (que cuida do Juizo Arbitral)." 21 (grifo acrescentado)

20 Vide BARROSO, Luís Roberto. Sociedade de Economia Mista Prestadora de Serviço Público. Cláusula Arbitral Inserida em Contrato Administrativo sem Prévia Autorização Legal. Invalidade. In: Temas de Direito Constitucional, Tomo II, Rio de Janeiro: Renovar, 2003, p. 624. Vale transcrever posição de Maria Sylvia Zanella Di Pietro nesse sentido: "A Lei $n^{\circ} 8.666 / 93$. com as alterações introduzidas pela Lei $n^{\circ} 8.883$, de 8.6.94, e pela Lei $n^{\circ} 9.648$, de 27.5.98, abrange todos os contratos por ela disciplinados sob a denominaçâa de contratos administrativos (arts. $1^{\circ} \mathrm{e} 54$ ), ainda que nem todos tenham essa natureza.(...)

No entanto, alguns desses contratos regem-se basicamente pelo direito privado, com sujeição a algunas normas de direito público constantes dessa lei. (...)

Houve, no entanto, uma evidente intenção do legislador de publicizar todos os contratos referidos; é o que decorre do artigo $62, \S 3^{\circ}$. que manda aplicar o disposto nos artigos 55 e 58 a 61 e demais normas gerais, no que couber. (...) Ficou quase inteiramente derrogado o direito comum, porque o legislador preferiu, em praticamente todos os contratos de que a Administração é parte, manter a sua posição de supremacia sobre o particular. " (Direito Administrativo, 13" ed., São Paulo: Atlas, 1999, pp. 240-241).

21 DALLARI, Adilson Abreu. Arbitragem na Concessão de Serviço Público. Revista de Informação Legislativa do Senado Federal 128/63-67, p. 65. No mesmo sentido, v. Mauro Roberto Gomes de Mattos (Contrato Administrativo e a Lei de Arbitragem. Revista de Direito Administrativo 223/115-131, pp. 124-125). 
"No Brasil, permitiu-se que o Estado e suas agências celebrassem convenção de arbitragem em casos especificos. 'Assim, tem-se a Lei 8.666/93 Lei de Licitações - art. 54'; (...)"22 (grifo acrescentado)

Ora, essa posição não deve prevalecer, pois os princípios da teoria geral dos contratos e as disposições de direito privado devem ser aplicadas somente supletivamente. Além disso, há normas expressas na Lei $n^{\circ} 8.666$ estabelecendo como obrigatória a cláusula de eleição do foro da sede da Administração (art. $55, \S 2^{\circ}$ ) e estendendo essa obrigatoriedade aos contratos da Administração cujo conteúdo seja regido, predominantemente, pelo direito privado (art. $62, \S 3^{\circ}$ ). Luís Roberto Barroso posiciona-se contra essa interpretação extensiva do art. 54 de forma taxativa:

"De todo modo, ainda que não houvesse norma em sentido exatamente contrário na mesma lei, seria implausivel supor que a aplicação supletiva de 'principios da teoria geral dos contratos', referida no art. 54 da Lei $n^{o}$ 8.666/93, aos quais se deve recorrer apenas após esgotado o arsenal teórico do direito público, pudesse servir de fundamento legal para o ajuste de arbitragem. A compreender a norma nesse sentido, qualquer instituto de direito privado, e especificamente de teoria geral dos contratos, poderia ser livremente empregado pelo administrador público, em burla evidente ao princípio da legalidade." 23

Com o advento da Lei $n^{\circ} 8.987$, de 1995 , verificamos uma evolução na matéria, eis que o art. 23, XV, estabeleceu como cláusula essencial do contrato de concessão a relativa "ao foro e 'ao modo amigável de solução de divergências contratuais"." (grifo acrescentado). ${ }^{24}$ Assim, a doutrina, quase que unanimemente, passou a identificar nessa disposição uma autorização à utilização da arbitragem nos contratos de concessão de serviços públicos. Sobre a interpretação da expressão modo amigável de solução de controvérsias, confira-se a posição de Cláudio Vianna de Lima:

"Estes modos são a mediação, a conciliação e a arbitragem. Na verdade são formas que se filiam, ao mesmo fundamento do princípio da autonomia

22 WALD, Arnoldo. Algumas Consideraçōes a Respeito da Cláusula Compromissória Firmada pelos Estados nas suas Relações Internacionais. Revista de Direito Bancário, do Mercado de Capitais e da Arbitragem 18/283.

23 BARROSO, Luís Roberto. Sociedade de Economia Mista Prestadora de Serviço Público. Cláusuia Arbitrai Inserida em Contrato Administrativo sem Prévia Autorização Legal. Invalidade. In: Temas de Direito Constitucional, Tomo II, Rio de Janeiro: Renovar, 2003, p. 625. O autor lembra ainda que a arbitragem constitui uma exceção às regras da jurisdição estatal e da inafastabilidade do controle judicial consagradas pela Constituição. Assim, por envolver a renúncia a um direito constitucional, sua interpretação deve ser estrita (p. 622).

24 Note-se que, apesar de o art. 23 só tratar das cláusulas essenciais dos contratos de concessão, por força do art. 40, caput e parágrafo único da Lei $n^{\circ} 8.987 / 95$, essa disposição aplica-se também às permissões de serviço público. 
da vontade. As partes em divergência confiam a pessoas estranhas ao conflito que as separa, a composição do mesmo". ${ }^{25}$

No mesmo sentido, veja-se Diogo de Figueiredo Moreira Neto:

"Ora, como só há três modos de solucionar amigavelmente controvérsias contratuais: pela mediação, pela conciliação e pela arbitragem, não resta a menor dúvida de que o legislador brasileiro a previu expressamente, embora sem explicitar, como uma das modalidades que 'devem' ser necessariamente adotadas". ${ }^{26}$

Não obstante o avanço implementado pela Lei ${ }^{\circ} 8.987 / 95$, é importante observar que a redação do artigo não é inequívoca, uma vez que não faz menção expressa à arbitragem, além disso, caberia aqui uma crítica à expressão utilizada pelo legislador, pois a arbitragem não é modo amigável, mas sim solução extra-judicial (de natureza jurisdicional) de controvérsias. ${ }^{27}$ Ademais, o inciso XV fala em foro $e$ modo

25 O autor destacou, ainda, que no Contrato de Concessão da Rodovia Juiz de Fora - Rio, assinado em 31 de outubro de 1995, foram incluídas disposições relativas ao processo amigável de soluções de divergências contratuais, com expressa referência a tribunal arbitral, já com base no permissivo do art. 23, XV, da Lei n 8.987/95. (A Lei de Arbitragem e o art. 23, XV, da Lei de Concessōes. Revista de Direito Administrativo, Rio de Janeiro 209/91-104, p. 101-102).

26 NETO, Diogo de Figueiredo Moreira. Arbitragem nos Contratos Administrativos. In: Mutações do Direito Administrativo, Rio de Janeiro: Renovar, 2000, p. 233. No mesmo sentido, v. WALD, Arnoldo, MORAES, Luiza Rangel de, WALD, Alexandre de M. O Direito de Parceria e a Nova Lei de Concessões, São Paulo: Revista dos Tribunais, 1996, p. 140; LEMES, Selma M. Ferreira. A Arbitragem e os Novos Rumos Empreendidos na Administração Pública: A Empresa Estatal, o Estado e a Concessão de Serviço Público. In: Aspectos Fundamentais da Lei de Arbitragem, MARTINS, Pedro Batista, LEMES, Selma M. Ferreira e CARMONA, Carlos Alberto, Rio de Janeiro: Forense, 1999, p. 194; LEMES, Selma M. Ferreira. Arbitragem na Concessão de Serviços Públicos - Arbitrabilidade Objetiva. Confidencialidade ou Publicidade Processual? Palestra proferida na reunião do Comitê Brasileiro de Arbitragem - CBAR realizada em São Paulo em 06.05.03, conforme disponibilizado pela Escola de Direito de São Paulo da Fundação Getúlio Vargas (FGV-EDESP/ FGV Law); MATTOS, Mauro Roberto Gomes de. Contrato Administrativo e a Lei de Arbitragem. Revista de Direito Administrativo 223/1 15-131, p. 125-126. Com posição bastante conservadora, negando a possibilidade de utilização da arbitragem com base no art. 23, XV, da Lei $\mathrm{n}^{\circ} 8.987 / 95$, vide Lúcia Valle Figueiredo: "Por força do dispositivo do inciso XV do art. 23 da Lei n. 8.987/95, que dispõe ser necessário constar do contrato o foro e o modo amigável de solução das divergências contratuais, cogitou-se da possibilidade de se utilizar o juízo arbitral. Ocorre que, consoante pensamos, o juizo arbitral, nos termos da Lei n. 9.307, de 23.9.1996, estaria, com a vênia devida daqueles que pensam em contrário, absolutamente descartado. A uma, porque destina-se aos direitos disponíveis, portanto näo poderia servir para dirimir questões em que está envolvido o interesse público. Demais disso, nos termos do art. 18 da mencionada Lei n. 9.307/96. 'o árbitro é juiz de fato e de direito, e a sentença que proferir não fica sujeita a recurso ou à homologação pelo Poder Judiciário', u que implicaria impossibilidade de haver recurso ao Judi. ciário, em franco desrespeito às regras constitucionais dos direitos e garantias individuais (art. $5^{\circ}$, incisos $\left.X X X V, L X I X, L X X, L X X I I I\right)$. (Curso de Direito Administrativo, $5^{n}$ ed., São Paulo: Malheiros, 2001, p. 101).

27 Confira-se a posiçāo de Clávio Valença Filho: "De inicio, conforme já demonstramos, a arbitragem não é método amigável de resolução de controvérsias, característica que não se 
amigável de solução de controvérsias, quando deveria ter falado "ou". Ora, as cláusulas de eleição de foro e arbitral são incompatíveis, salvo se cada uma tiver o seu escopo definido de forma precisa e inequívoca. Caso contrário, a presença das duas cláusulas no mesmo contrato pode ensejar dúvida ao intérprete quanto a qual delas deverá prevalecer. ${ }^{28}$

Após o advento da Lei $\mathrm{n}^{\circ} 8.987 / 95$, parte da doutrina passou a defender que a disposição do art. 23, XV, constituía uma permissão genérica à utilização da arbitragem nos contratos administrativos, e não somente nos contratos de concessão e permissão. Essa é a posição de Caio Tácito:

"A questão do cabimento do juizo arbitral, em matéria pertinente a contratos administrativos, assumiu aspecto novo com o advento da Lei $n$. 8.987, de 13 de fevereiro de 1995, que dispõe sobre concessões e permissões de serviços e obras públicas.(...)

A partir do expresso critério quanto aos contratos de concessão, cujo modelo federal se transmite como norma geral aos planos estadual e municipal, a doutrina passou a reconhecer o ingresso do arbitramento em matéria administrativa." 29

coaduna com métodos como a conciliação, a mediação e o mini-trial; não pela arbitragem. Por se tratar de método eminentemente jurisdicional de resolução de controvérsias, a decisão proferida pelo árbitro é uma verdadeira sentença, enquanto decisão resultante dos métodos amigáveis tem, normalmente, natureza contratual. Não se pode, destarte, confundir arbitragem e modos amigáveis de resolução de controvérsias, primeira razão pela qual a arbitragem não estaria autorizada pelo referido art. 23." Note-se, contudo, que o autor confere outra interpretação ao art. 23, XV, de modo a permitir a utilização da arbitragem: "Está implícito na autorização para a escolha de um método amigável a atribuição de disponibilidade a tais direitos. Conclui-se: podendo a administração dispor de direitos através da resolução de litígios por métodos amigáveis, com mais razão poderá submetê-los a uma decisão jurisdicional, prolatada por um tribunal arbitral. Quem pode mais pode menos." (Arbitragem e Contratos Adlinistrativos. Revista de Direito Bancário, do Mercado de Capitais e da Arbitragem 9/371-373).

28 Vide crítica à redação do dispositivo feita por Pedro Batista Martins ( $O$ Poder Judiciário e a Arbitragem: Quatro Anos da Lei $n^{\circ} 9.307 / 96$ ( $3^{\circ}$ Parte). Revista Forense 359/165, p. 177). Eros Roberto Grau, em parecer sobre o tema, entende não haver qualquer incompatibilidade entre a cláusula arbitral e a cláusula de eleição de foro em um mesmo contrato: "Tenho como evidente, no caso, a circunstância de a cláusula de eleição de foro dirigir-se a situaçōes que não possam sujeitar-se à arbitragem. De outro lado, a cláusula de foro fixa a competência para a i) execução do julgado arbitral, ii) ação de nulidade da arbitragem ou iii) formulação dos pedidos a que se

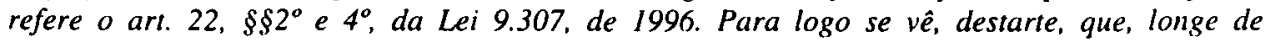
consubstanciar incompatibilidade, essas cláusulas se complementam e têm por objetivo conferir o maior grau de efetividade possivel ao sistema de resolução de conflitos que surgirem a respeito do contrato celebrado." (GRAU, Eros Roberto. Da Arbitrabilidade de Litigios Envolvendo Sociedades de Economia Mista e da Interpretação de Cláusula Compromissória. Revista de Direito Bancário, do Mercado de Capitais e da Arbitragem 18/ 395-405, p. 404-405).

29 TÁCITO, Caio. O Juízo Arbitral em Direito Administrativo. In: Reflexōes sobre Arbitragem: in memorian do Desembargador Cláudio Vianna de Lima. MARTINS, Pedro A. Batista e GARCEZ, José Maria Rossani (Coords.), São Paulo: LTr, 2002, p. 26. 
Luís Roberto Barroso critica essa extensão da regra do art. $23, \mathrm{XV}$, a todos os contratos administrativos:

"Por qual razão uma regra excepcional autorizando a Administração a
renunciar à jurisdição estatal no âmbito de contratos de concessão deveria
ser aplicada a todo e qualquer contrato administrativo? (...) Ora, a Lei de
Concessões trata dos contratos de concessões e não dos contratos adminis-
trativos em geral." 30

Na mesma linha da Lei de Concessões, a Lei $n^{\circ}$ 9.472/97 - Lei Geral de Telecomunicações - estatuiu, no art. $93, \mathrm{XV}$, que os contratos de concessão deverão indicar o foro e o modo para solução extrajudicial das divergências contratuais. A única diferença é que essa lei utilizou a expressão "solução extrajudicial", em vez de "solução amigável".

A Lei $n^{\circ}$ 9.478/97 - Lei do Petróleo -, em seu art. 43, inciso X, estabelece como cláusula essencial do contrato de concessão as regras sobre solução de controvérsias, inclusive a conciliação e a arbitragem internacional. ${ }^{31}$ Adicionalmente, a Lei do Petróleo prevê a utilização da arbitragem em dois outros dispositivos (arts. 20 e 27), que suscitam dúvida sobre se se referem a uma arbitragem propriamente dita ou a um procedimento de solução de conflitos de natureza administrativa no âmbito da agência reguladora. ${ }^{32} \mathrm{O}$ art. 20 prevê que o regimento interno da ANP disporá sobre os procedimentos a serem adotados para a solução de conflitos entre agentes econômicos, e entre estes e usuários e consumidores, com ênfase na conciliação e no arbitramento. E o parágrafo único do art. 27 prevê que na hipótese de

30 BARROSO, Luís Roberto. Sociedade de Economia Mista Prestadora de Serviço Público. Cláusula Arbitral Inserida em Contrato Administrativo sem Prévia Autorização Legal. Invalidade. In: Temas de Direito Constitucional, Tomo II, Rio de Janeiro: Renovar, 2003, p. 626.

31 Art. 43 - "O contrato de concessão deverá refletir fielmente as condições do edital e da proposta vencedora e terá como cláusulas essenciais: $X$ - as regras sobre solução de controvérsias, relacionadas com o contrato e sua execução, inclusive a conciliação e a arbitragem internacional" (grifo acrescentado). Logicamente a expressão arbitragem internacional deve ser interpretada como englobando também a arbitragem interna. Nesse sentido, vide a opiniāo de Pedro Batista Martins ( $O$ Poder Judiciário e a Arbitragem: Quatro Anos da Lei $n^{\circ}$ 9.307/96 (3 Parte). Revista Forense $359 / 165$, p. 177).

$32 \mathrm{O}$ art. 20 trata do processo decisório da ANP para solução dos conflitos entre os agentes econômicos, e entre estes e usuários e consumidores. Assim, certamente a decisão da ANP será imposta a esses agentes, sem que tenha havido uma prévia manifestação de vontade no sentido de se submeterem a essa decisão "arbitral". O mesmo ocorre com relação à unitização (art. 27). Trata-se de decisão consubstanciada em laudo arbitral imposto pela ANP aos concessionários de blocos vizinhos, que não foram capazes de chegarem a um acordo para a individualização da produção. A Lei prevê a realização de uma arbitragem entre dois concessionários que não acordaram expressamente em se submeter à arbitragem, uma vez que não há um contrato celebrado entre eles, mas entre cada um deles com a ANP. Nesse sentido, indaga-se se a Lei do Petróleo não quis tão-somente prever uma instância administrativa para solução dos conflitos, chamando-a equivocadamente de arbitragem. 
campos que se estendam por blocos vizinhos (unitização) em que os concessionários não consigam chegar a um acordo quanto à individualização da produção, caberá à ANP, com base em laudo arbitral, determinar como serão equiitativamente apropriados os direitos e obrigações sobre os blocos. ${ }^{33}$

Por fim, a recente Lei $n^{\circ} 10.433$, de 2002, que autoriza a criação do Mercado Atacadista de Energia Elétrica - MAE, prevê em seu artigo $2^{\circ}$ que a solução das eventuais divergências entre os agentes integrantes do MAE se dará por arbitragem, autorizando expressamente as empresas públicas e sociedades de economia mista, suas subsidiárias e controladas, titulares de concessão, permissão e autorização, autorizadas a aderirem ao MAE, a se submeterem à arbitragem. ${ }^{34}$

Conclui-se, portanto, que partimos de uma regra proibitiva absoluta (Decreto $n^{\circ} 15.783 / 22$ ), passamos por períodos de pequena relativização (exceções criadas pelo Decreto-lei $n^{\circ} 2.300 / 86$ e pela Lei $n^{\circ} 8.666 / 93$ no tocante a algumas hipóteses de licitação internacional), até chegarmos à tendência atual de se permitir cada vez mais a utilização da arbitragem em alguns contratos específicos da Administração Pública, como por exemplo, nos contratos de concessão e permissão e nos contratos de concessão para exploração e produção de petróleo. Todavia, o Direito Brasileiro ainda carece de uma lei que altere o $\S 2^{\circ}$ do art. 55 da Lei $n^{\circ} 8.666 / 93$, e que crie uma permissão genérica à utilização da arbitragem nos contratos celebrados pela Administração Pública, disciplinando seus limites e particularidades. ${ }^{35}$ Não se pode

33 Selma Lemes interpreta esse artigo como prevendo hipótese de arbitramento, perícia, e não de arbitragem (A Arbitragem e os Novos Rumos Empreendidos na Administração Pública: A Empresa Estatal, o Estado e a Concessão de Serviço Público. In: Aspectos Fundamentais da Lei de Arbitragem, MARTINS, Pedro Batista, LEMES, Selma M. Ferreira e CARMONA, Carlos Alberto, Rio de Janeiro: Forense, 1999, pp. 204-205). Sobre arbitragem na indústria do petróleo, vide: ROSADO, Marilda de Sá Ribeiro. Direito do Petróleo: Joint Ventures na Indústria do Petróleo, $2^{\mathrm{a}}$ ed., Rio de Janeiro: Renovar, 2003; DOLINGER, Jacob e TIBURCIO, Carmen. Arbitragem na Indústria do Petróleo. In: Direito Internacional Privado - Parte Especial: Arbitragem Comercial Internacional, Rio de Janeiro: Renovar, 2003; BUCHEB, José Alberto. A Arbitragem Internacional nos Contratos da Indústria do Petróleo, Rio de Janeiro: Lumen Juris, 2002, pp. 31-33.

34 Art. $2^{\circ}-" \S 3^{\circ}-A$ forma de solução das eventuais divergências entre os agentes integrantes do MAE, será estabelecida na Convenção de Mercado e no estatuto, que contemplarão e regulamentarão mecanismo e convenção de arbitragem, a eles se aplicando os arts. 267, inciso VII; 301 , inciso IX; 520, inciso VI; e 584, inciso III, do Código de Processo Civil"; " $\$ 4^{\circ}-$ Ficam as empresas públicas e sociedades de economia mista, suas subsidiárias ou controladas, titulares de concessão, permissão e autorização a aderirem ao MAE, inclusive ao mecanismo e à convenção de arbitragem previstos no $\$ 3^{\circ "}$.

35 Joaquim Simões Barbosa e Carlos Affonso Pereira de Souza defendem que a alteração do art. $55, \S 2^{\circ}$ para permitir a arbitragem de forma clara e inequívoca seria uma das formas de se alcançar maior segurança com relação ao tema. A outra forma seria através da construção de uma jurisprudência favorável. (Arbitragem nos Contratos Administrativos: Panorama de uma Discussão a ser Resolvida. In: Arbitragem Interna e Internacional (Questões de Doutrina e da Prática). ALMEIDA, Ricardo Ramalho (Coord.), Rio de Janeiro: Renovar, 2003, p. 273. Ainda sobre a necessidade de alteração da Lei $n^{\circ} 8.666 / 93$, de modo a contemplar a possibilidade da adoção da arbitragem, $v$. Leon Frejda Szklarowsky (Arbitragem e os Contratos Administrativos. Internet: "http://www.teiajuridica.com/a/arbcontt.htm. Acesso em 10.11.01). 
estender essas autorizaçc̃es específicas criadas por algumas leis a todos os contratos da Administração Pública.

\section{$V$ - Arbitrabilidade objetiva: direitos disponiveis $x$ direitos indisponiveis}

Verificada a questão da arbitrabilidade subjetiva, cumpre analisar a questão sob o prisma da arbitrabilidade objetiva. Ou seja, deve-se também verificar a possibilidade ou não da adoção da arbitragem pela Administração, levando-se em conta a natureza dos direitos envolvidos - disponíveis ou indisponíveis.

Na doutrina, não é pacífica a temática relativa à natureza dos direitos envolvidos nos contratos celebrados pela Administração Pública, ou seja, se todo contrato da Administração envolve somente direitos indisponíveis ou se em alguns casos a Administração atua tal como um particular, estando em jogo direitos disponíveis.

Nesse sentido, Maria Sylvia Di Pietro registra que existem grandes controvérsias entre os doutrinadores acerca dos contratos administrativos e sintetiza três correntes: 1) a que nega a existência de contrato administrativo, uma vez que, em virtude da supremacia da Administração, não se observa o princípio da igualdade entre as partes, o da autonomia da vontade e o da força obrigatória das convenções, caracterizadores de todos os contratos - defendida por Oswaldo Aranha Bandeira de Mello; 2) a que considera que todos os contratos celebrados pela Administração são contratos administrativos, em razão do regime jurídico administrativo - defendida por José Roberto Dromi; 3 ) a que aceita a existência dos contratos administrativos, como espécie do gênero contrato, com regime jurídico de direito público, derrogatório e exorbitante do direito comum, distintos dos contratos privados da Administração defendida pela maioria da doutrina, inclusive por Maria Sylvia Di Pietro. ${ }^{36}$

Poder-se-ia inferir a partir das três correntes mencionadas acima que, para os adeptos da primeira e segunda correntes (minoritárias), a Administração estaria impossibilitada de se valer da arbitragem. Para a segunda corrente, a arbitragem estaria vedada para os contratos administrativos, em razão do regime jurídico de direito público e da natureza indisponível dos direitos envolvidos, o que contraria o escopo da arbitragem previsto no art. $1^{\circ}$ da Lei de Arbitragem - controvérsias envolvendo direitos patrimoniais disponíveis. Nesse sentido, Renato Geraldo Mendes

36 DI PIETRO, Maria Sylvia Zanella. Direito Administrativo, 13 ed., São Paulo: Atlas, 2001, pp. 232-233. José Cretella Júnior também adota essa terceira posição: “(...) nem todo contrato 'da' Administração é contrato administrativo, pois este é espécie daquele. É aquele quando submetido a determinado regime jurídico, que não é o de direito comum ou de direito privado, mas regime especial: o regime jurídico de direito público, exorbitante e derrogatório do direito comum. (...) Os contratos privados da Administração regem-se pelo Código Civil ou Comercial, os contratos públicos da Administração, ao contrário, pelas características especialissimas de que se revestem, estäo sujeitos a regime autônomo, típico, que ultrapassa ou exorbita as normas do direito comum. o que é evidente, porque as pessoas públicas, quando contratam, não se encontram na mesma situação que os particulares." (Direito Administrativo Brasileiro, Rio de Janeiro: Forense, 1999. p. 354). 
afirma de forma taxativa: "Não é possivel a eleição de juizo arbitral no âmbito dos contratos administrativos, uma vez que os direitos e interesses que os compõem são, por imposição legal, indisponiveis." 37

Já para os adeptos da terceira corrente - que admitem a dicotomia entre contratos administrativos e contratos privados da Administração - poder-se-ia inferir que estaria admitida a arbitragem nos contratos privados, por envolver direitos disponíveis. Verifica-se, todavia, que não há na doutrina uniformidade quanto à forma de diferenciar esses contratos. Há autores que distinguem contratos administrativos de contratos de direito privado; outros preferem classificar a atuação estatal - de gestão, negocial ou de império; alguns defendem a distinção entre a natureza das cláusulas dos contratos administrativos; e, por fim, há autores que só distinguem os direitos envolvidos - primários e secundários, indisponíveis e disponíveis, conforme veremos abaixo.

Para Diogo de Figueiredo Moreira Neto existem duas categorias de interesses públicos, os primários e os secundários (ou derivados), sendo que os primeiros são indisponíveis e o regime público é indispensável, ao passo que os segundos possuem natureza instrumental, existindo para que os primeiros sejam satisfeitos e resolvem-se em relações patrimoniais e tornam-se indisponíveis na forma da lei. $\mathrm{O}$ autor afirma que essa distinção entre as atividades administrativas, no sentido de situar quais delas estão no campo do direito privado, tem sido buscada de longa data no Direito Administrativo. Além disso, registra que, após um período em que a distinção foi buscada no conceito de serviço público, desenvolveu-se a teoria da finalidade pública, uma vez que o critério diferencial não pode ser apenas o interesse público, já que presente em toda atividade da Administração. Para ele, a teoria dos fins, distinguindo os primários dos secundários, parece ainda ser a mais indicada para definir a existência ou não da disponibilidade administrativa de interesses e de seus correlatos direitos. Com relação à possibilidade de o Estado se valer da arbitragem, o autor afirma:

"Toda a questão do cabimento da arbitragem na órbita interna se reduz à definição do campo contratual em que a Administração negocia e estatui como qualquer particular, excluidas, portanto, quaisquer cláusulas em que seja prevista a satisfação de um interesse finalístico da sociedade, cometido ao Estado, este sim, indisponivel." 38

De forma semelhante, Caio Tácito ensina que os contratos administrativos não se confundem com os contratos de direito privado pela finalidade a que se destinam no atendimento do interesse público. $O$ autor ressalta a distinção entre as cláusulas financeiras dos contratos administrativos - onde a solução amigável é fórmula

37 MENDES, Renato Geraldo. Lei de Licitações e Contratos Anotada, 3" ed., Curitiba: Znt Editora, 1998, p. 122, nota 847.

38 NETO, Diogo de Figueiredo Moreira. Arbitragem nos Contratos Administrativos. In: Mutações do Direito Administrativo, Rio de Janeiro: Renovar, 2000, p. 226-228. 
substitutiva do dever primário de cumprimento da obrigação assumida ${ }^{39}-\mathrm{e}$ as cláusulas que contemplam interesses públicos de uso de bens públicos ou a fruição de vantagens que não se compadecem com a disponibilidade ou a alienação do patrimônio estatal - onde não se pode utilizar a arbitragem. Caio Tácito conclui: "Em suma, nem todos os contratos administrativos envolvem, necessariamente, direitos indisponiveis da Administração".

Pedro Batista Martins distingue a atuação estatal entre atos de império arbitragem vedada —, e atos de gestão - arbitragem permitida -:

"Sendo o ajuste contratado no desempenho de atividade do Estado com preponderância do seu poder político, agindo, pois, com causa de utilidade pública, impõe-se as cláusulas e condições acordadas no ordenamento de direito público, cujo conteúdo não é passivel de transação. Estamos, nesse caso, frente ao ato 'jus imperii', ao qual se curva o particular e, a reboque, a cláusula compromissória.

Contudo, se a relação entabulada pelo Estado ou por um de seus entes de direito público refletir ato de natureza privada, estão estes atuando no cenário comercial, desprovidos das prerrogativas do direito público, equiparando-se, pois, aos particulares contratantes. Assim, ao praticar atos 'jus gestionis', podem comprometer-se em sujeitar-se à solução arbitral e, inclusive, aplicar lei estrangeira à própria controvérsia.

Tratando-se de contrato 'jure gestione', legítima e válida a cláusula arbitral, tanto no trato das relações de direito interno quanto internacional." 40

Sergio de Andréa Ferreira posiciona-se a favor da utilização da arbitragem nos litígios de direito público, com a limitação das questões de ordem pública, embora defenda a necessidade da criação de lei especial regulando a matéria. ${ }^{41}$ Vale dizer,

39 "Na medida em que é permitido à Administração Pública, em seus diversos órgãos e organizações, pactuar relações com terceiros, especialmente mediante a estipulação de cláusulas financeiras, a solução amigável é fórnula substitutiva do dever de cumprimento da obrigação assumida. Assim como é lícito, nos termos do contrato, a execução espontânea da obrigação, a negociação - e, por via de conseqüência, a convenção da arbitragem - será meio adequado a tornar efetivo o cumprimento obrigacional quando compativel com a disponibilidade de bens." TÁCITO. Caio. O Juizo Arbitral em Direito Administrativo. In: Reflexões sobre Arbitragem: in memorian do Desembargador Cláudio Vianna de Lima. MARTINS, Pedro A. Batista e GARCEZ, José Maria Rossani (Coords.), São Paulo: LTr, 2002, p. 27.

40 MARTINS, Pedro Batista. O Poder Judiciário e a Arbitragem: Quatro Anos da Lei n 9.307/96 (3ªrte). Revista Forense 359/165, p. 173.

41 "Para as questões de direito público, haverá de existir lei própria (especial, neste sentido, não obstante, geral), editável por cada entidade político-federativa, cabendo à União, também em 'lex specialis' de direito público, dispor, nos termos dos arts. 22, XXVII, 24, XI, e 30, II da CF, sobre normas gerais nacionais quanto à cláusula compromissória e ao compromisso, enquanto modalidades de contratação; e de procedimento em matéria processual, respeitada a competência federal. privativa, segundo o art. 22, I da Carta Magna." (FERREIRA, Sergio de Andréa. A Arbitragem e a Disponibilidade de Direitos no Ius Publicum Interno. In: Reflexões sobre Arbitragem: in 
lei especial de aplicação genérica, sem necessidade de lei para cada caso. ${ }^{42}$ Todavia, admite o autor, enquanto não houver lei especial, a aplicação da Lei $n^{\circ} 9.307 / 96$ para as arbitragens domésticas de natureza negocial, com algumas limitações. ${ }^{43}$

Por fim, merece destaque o entendimento de Luís Roberto Barroso, que ensina que o fato de a atuação estatal envolver direitos indisponíveis não impede per se a utilização da arbitragem, pois os direitos indisponíveis da Administração tornam-se disponíveis pela lei:

"Ora, como é corrente, os interesses públicos e direitos a eles associados são presumidamente indisponiveis, de modo que, em geral, não podem ser submetidos à arbitragem. 'O entendimento convencional é o de que para que um interesse público, indisponivel como regra, venha a tornar-se disponivel, é necessária uma manifestação legislativa que afaste a presunção legal' $(. .) "$.

Adicionalmente, registra o autor não serem necessárias duas manifestações legislativas: uma para satisfazer o princípio da legalidade — arbitrabilidade subjetiva - e outra para tornar o direito disponível — arbitrabilidade objetiva:

"É razoável considerar que a mesma lei que autoriza a Administração a clausular arbitragem em determinado espaço de atuação (como, e.g., a Lei de Concessóes) implicitamente considera como disponiveis os interesses públicos ali envolvidos; caso contrário, eles não poderiam estar sujeitos ao juízo arbitral. Isto é: não são necessárias duas manifestações legislativas autônomas." 45

memorian do Desembargador Cláudio Vianna de Lima. MARTINS, Pedro A. Batista c GARCEZ, José Maria Rossani (Coords.), São Paulo: LTr, 2002, pp. 54-55).

42 "Inexiste o pressuposto necessário da autorização legislativa caso a caso: ou se tem a lex specialis' geral, por si suficiente, ou, na sua falta, lei especifica para a hipótese, com o estabelecimento da disciplina pertinente." Idem.

43 "Na ausência da 'lex specialis', a Lei n. 9.307/96 pode ser aplicada às contendas públicas internas, atendida a distinção entre aquilo que é de ordem pública e o que é negocial; e como exclusão dos permissivos que autorizam o julgamento que nāo seja de direito, mas de equiidade, $e$ que deixam, à livre escolha das partes, as regras de direito que serão aplicadas; ou julgamento que se baseie, também 'ex voluntae', não na regra jurídica incidente, mas em princípios gerais de direito, usos e costumes, não embasados na legislação de regência." Idem.

44 BARROSO, Luís Roberto. Sociedade de Economia Mista Prestadora de Serviço Público. Cláusula Arbitral Inserida em Contrato Administrativo sem Prévia Autorização Legal. Invalidade. In: Temas de Direito Constitucional, Tomo II, Rio de Janeiro: Renovar, 2003, p. 628. Observe-se que, como mencionado supra, o autor no referido parecer opinou contrariamente à adoção da arbitragem em razão das particularidades do caso concreto, especialmente em virtude da aplicação do art. $55, \S 2^{\circ}$, da Lei $n^{\circ} 8.666 / 93$. Todavia, o autor registra não defender a contrariedade absoluta à adoção da arbitragem pela Administração Pública: "Também não se estará sustentando aqui que a solução arbitral é constitucionalmente incompativel com as disputas que envolvam a Administração Pública; isto é, que a Administração nunca poderia submeter-se à arbitragem, pois não partilhamos desse entendimento." (p. 614)

45 Idem. 
Assim, poder-se-ia concluir a partir dos autores citados que, no tocante à arbitrabilidade objetiva, a maior parte da doutrina entende ser possível a utilização da arbitragem quando a atuação da Administração Pública envolver direitos disponíveis, em consonância com o art. $1^{\circ}$ da Lei $n^{\circ} 9.307 / 96$.

\section{$V I$ - Particularidades das empresas públicas e sociedades de economia mista}

Como se sabe, as empresas públicas e sociedades de economia mista ("empresas estatais") compõem a chamada Administração Pública indireta. Por meio delas o Estado explora atividade econômica ou presta um serviço público. Assim, quando as empresas estatais exploram atividade econômica, sujeitam-se às normas do art. $173^{46}$ da Constituição Federal e, por outro lado, quando o Estado delas se utiliza para a prestação de um serviço público, aplica-se o art. $175^{47}$ da Constituição Federal de $1988 .^{48}$

Com relação às empresas públicas e sociedades de economia mista exploradoras de atividade econômica, como o $\S 1^{\circ}$ do art. 173, em sua redação original, estabelecia que a empresa pública e a sociedade de economia mista que explorassem atividade econômica sujeitavam-se ao regime jurídico próprio das empresas privadas, inclusive quanto às obrigações trabalhistas e civis, parte da doutrina defendia que estaria permitida a utilização da arbitragem. Argumentava-se que se as empresas privadas podiam se submeter à arbitragem, também poderiam fazê-lo as empresas estatais exploradoras de atividade econômica, pois a elas se aplicava o mesmo regime jurídico. Nesse sentido, vide posição de Selma Lemes:

"Destarte, para o caso vertente, concentrar-nos-emos na Empresa Estatal que desenvolve atividade econômica em sentido estrito, a qual a teor do disposto no art. $173, \S l^{\circ}$, 'se sujeita ao regime jurídico próprio das em-

46 Art. 173 - "Ressalvados os casos previstos nesta Constituição, a exploração direta de atividade econômica pelo Estado só será permitida quando necessária aos imperativos da segurança nacional ou a relevante interesse coletivo, conforme definidos em lei."

47 Art.175 - "Incumbe ao Poder Público, na forma da lei, diretamente ou sob o regime de concessão ou permissão, sempre através de licitação, a prestação de serviços públicos."

48 Nesse sentido, v. Maria Sylvia Zanella Di Pietro: "Isto porque, como o artigo 173 cuida especificamente da atividade de nutureza privada, exercida excepcionalmente pelo Estado por razões de segurança nacional ou interesse coletivo relevante, hä que se concluir que as normas dos $\$ \S I^{\circ}$ e $2^{\circ}$ só incidem nessa hipótese. Se a atividade for econômica (comercial ou industrial) mas assumida pelo Estado como serviço público, tais normas não têm aplicação, incidindo, entäo, o artigo 175 da Constituição, segundo o qual incumbe ao Poder Público, na forma da lei, diretamente ou sob regime de concessão ou permissão, sempre através de licitação, a prestação de serviços públicos. Isto quer dizer que a empresa estatal que desempenha serviço público é concessionária de serviço público submetendo-se à norma do artigo 175 e ao regime jurídico dos contratos administrativos, com todas as suas cláusulas exorbitantes, deveres perante os usuários e direito ao equilíbrio econômico-financeiro." (Direito Administrativo, 13ª ed., São Paulo: Atlas, 2001, p. 375). 
presas privadas, haja vista que estaremos diante de direitos patrimoniais disponiveis', condição 'sine qua non' para o estudo da arbitragem. (...)

Assim. 'quanto à capacidade pessoal em valer-se da arbitragem é indubitável que a Empresa Estatal a possui'. Igualmente, quanto ao critério objetivo, as questões advindas de contratos firmados entre a Empresa Estatal que explora atividade econômica em sentido estrito e particulares dizem respeito a direitos patrimoniais disponiveis. São suscetiveis de transação. Podem, portanto, eleger a instância arbitral para solucionar pendências advindas de contratos celebrados com particulares." 49 (grifo acrescentado)

Ocorre que o art. 22, XXVII, da Constituição Federal, previa dentre as competências legislativas da União a de estabelecer normas gerais de licitação e contratação em todas as modalidades para a administração pública, direta e indireta, nas diversas esferas de governo. ${ }^{50} \mathrm{Em}$ observância ao comando previsto nesse artigo, o legislador ordinário promulgou a Lei $n^{\circ} 8.666 / 93$, cuja aplicação estende-se também à Administração Pública indireta, por força dos arts. $1^{\circ}$, parágrafo único, e 119 , que estabelecem, respectivamente, a extensão à empresa estatal do regime da Lei e a edição de regulamento próprio aprovado pela autoridade de nível superior, sujeitando-se às disposições da Lei. ${ }^{51}$ Sendo assim, o obstáculo imposto pelo art. $55, \S 2^{\circ}$ da Lei $n^{\circ} 8.666 / 93$ (prevê obrigatoriedade de cláusula que declare competente o foro da sede da Administração) à utilização da arbitragem também se aplicava às empresas estatais. Confira-se interessante crítica feita por Joaquim Simões Barbosa e Carlos Affonso Pereira de Souza ao art. 22, XXVII da Constituição:

"(...) a Constituição Federal, ao mesmo tempo em que expressamente submetia a sociedade de economia mista 'ao regime jurídico próprio da empresa privada' (art. $\left.173, \S 1^{\circ}\right)$, mandava aplicar as mesmas 'normas gerais de licitação e contratação, em todas as modalidades'(art. 22, inciso XXVII), indistintamente, à administração pública direta e indireta, aí também incluídas, portanto, as sociedades de economia mista.

49 LEMES, Selma M. Ferreira. A Arbitragem e os Novos Rumos Empreendidos na Administração Pública: A Empresa Estatal, o Estado e a Concessão de Serviço Público. In: Aspectos Fundamentais da Lei de Arbitragem, MARTINS, Pedro Batista, LEMES, Selma M. Ferreira e CARMONA, Carlos Alberto, Rio de Janeiro: Forense, 1999, pp. 178 e 183.

50 Art. 22 - "Compete privativamente à União legislar sobre: XXVII - normas gerais de licitação e contratação, em todas as modalidades para a administração pública, direta e indireta. incluídas as fundações instituídas e mantidas pelo Poder Público, nas diversas esferas de governo. e empresas sob seu controle."

51 Art. $1^{\circ}$, parágrafo único - "Subordinam-se ao regime desta Lei, além dos órgãos da administração direta, os fundos especiais, as autarquias, as fundaçōes públicas, as empresas públicas, as sociedades de economia mista e demais entidades controladas direta ou indiretamente pela União, Estados, Distrito Federal e Municipios"; Art. 119 - “As sociedades de economia mista, empresas e fundações públicas e demais entidades controladas direta ou indiretamente pela União e pelas entidades referidas no artigo anterior editarão regulamentos próprios devidamente publicados, ficando sujeitas às disposições desta Lei." 
Isso retirava da significação prática do art. $173, \S 1^{\circ}$, pois o regime jurídico próprio da empresa privada não era aplicável às sociedades de economia mista em um dos aspectos mais importantes da sua existência: nada menos do que todas as modalidades de contratos por elas celebrados ficavam excluidos desse regime e submetidos às mesmas normas rígidas e extravagantes criadas para a administração pública direta." 52

Note-se, contudo, que alguns autores continuavam defendendo a possibilidade de utilização da arbitragem para as empresas estatais exploradoras de atividade econômica, em razão de não estarem estas sujeitas obrigatoriamente ao procedimento licitatório previsto na Lei $n^{\circ} 8.666 / 93$, não se lhes aplicando o art. $55, \S 2^{\circ}$. Esse era o entendimento de Selma Lemes, que defendia que como a empresa estatal atua como particular, estaria dispensada do dever de licitar, eis que o procedimento licitatório seria inconveniente com a normalidade de suas atuações na esfera econômica. Os arts. $1^{\circ}$ e 119 da Lei de Licitações deveriam ser interpretados no sentido da necessidade de observância dos princípios do procedimento licitatório, não estando adstritas a seguir fielmente as disposições da Lei $n^{\circ} 8.666 .{ }^{53}$

Dessa forma, Selma Lemes concluía pela capacidade pessoal da empresa estatal de se valer da arbitragem - questão relativa à arbitrabilidade subjetiva —, conforme trecho transcrito acima. Somente nesse ponto discordamos da autora, pois mesmo que se defendesse a não aplicação do art. $55, \S 2^{\circ}$ da Lei $n^{\circ} 8.666$, ainda assim seria necessária a existência de lei expressamente autorizando a adoção da arbitragem pelas empresas estatais. Como vimos, a aplicação do princípio da legalidade para a Administração Pública exige não somente que não haja lei proibindo, mas que haja lei expressamente permitindo.

A Emenda Constitucional $n^{\circ} 19 / 98$ - que alterou os arts. 22, XXVII, e 173 da Constituição de 1988 - previu a edição de estatuto jurídico para as empresas públicas e sociedades de economia mista exploradoras de atividade econômica, com observância dos princípios da Administração Pública no que concerne à licitação e contratações, contemplando o que já vinha sendo defendido por parte da doutrina. Confira-se a nova redação, in verbis:

"Art. 22. Compete privativamente à União legislar sobre: XXVII - normas gerais de licitação e contratação, em todas as modalidades, para as administrações públicas diretas, autárquicas e fundacionais da União, Estados, Distrito Federal e Municipios, obedecido o disposto no

52 BARBOSA, Joaquim Simões e SOUZA, Carlos Affonso Pereira de. Arbitragem nos Contratos Administrativos: Panorama de uma Discussão a ser Resolvida. In: Arbitragem Interna e Internacional (Questões de Doutrina e da Prática). ALMEIDA, Ricardo Ramalho (Coord.), Rio de Janeiro: Renovar, 2003, pp. 278-279.

53 LEMES, Selma M. Ferreira. A Arbitragem e os Novos Rumos Empreendidos na Administração Pública: A Empresa Estatal, o Estado e a Concessāo de Serviço Público. In: Aspectos Fundamentais da Lei de Arbitragem, MARTINS, Pedro Batista, LEMES, Selma M. Ferreira e CARMONA, Carlos Alberto, Rio de Janeiro: Forense, 1999, pp. 182-183. 
art. 37, XXI, 'e para as empresas públicas e sociedades de economia mista, nos termos do art. $173, \S 1^{\circ}$, III'."

"Art. 173. Ressalvados os casos previstos nesta Constituição, a exploração direta de atividade econômica pelo Estado só será permitida quando necessária aos imperativos da segurança nacional ou a relevante interesse coletivo, conforme definidos em lei.

$\$ 1$ 'A lei estabelecerá o estatuto jurídico da empresa pública, da sociedade de economia mista e de suas subsidiárias que explorem atividade econômica' de produção e comercialização de bens ou de prestação de serviços, dispondo sobre: (...)

III - licitação e contratação de obras, serviços, compras e alienações, 'observados os princípios da administração pública'; (...)" (grifo acrescentado)

Assim, parte da doutrina passou a conferir eficácia imediata ao art. 173, $\S 1^{\circ}$, III, defendendo que as empresas públicas e sociedades de economia mista exploradoras de atividade econômica não mais estariam sujeitas à Lei $n^{\circ}$ 8.666/93, apesar de ainda não ter sido editada a lei com o estatuto jurídico dessas empresas. Nesse sentido, podemos citar Diogo de Figueiredo Moreira Neto:

"As sociedades de economia mista foram nominadamente excluídas do alcance das normas gerais, de competência da Uniāo, previstas no art. 22, XXVII, da Constituiçāo e, em consequiência, do regime geral instituído pela Lei $n^{\circ} 8.666 / 93$, mas o mesmo dispositivo constitucional, in fine, a sujeita a um específico regime para as suas licitações e contratações, dispondo no já referido estatuto jurídico (art. $173, \S I^{\circ}$, III).

Por estarem submetidas a esse regime legal especial, excepcionalmente limitador da livre contratação, fica afastado não só o regime legal geral de licitações e contratações administrativas, fundado no art. 22, XVII, CF, como também a sua aplicação subsidiária, pois nenhum regime puiblico, pouco importa se geral ou especial, poderá ser aplicado para ampliar ou agravar uma estrita derrogação do regime próprio estabelecido no art. 173. $\S 1^{\circ}$, Il da Constituição." 54

Nessa linha, como não haveria mais que se falar na aplicação do $\S 2^{\circ}$, do art. 55, da Lei $n^{\circ} 8.666 / 93$ às empresas estatais exploradoras de atividade econômica, poder-se-ia concluir que estava abolido o obstáculo à utilização da arbitragem..$^{55}$

54 NETO, Diogo de Figueiredo Moreira. Sociedades de Economia Mista e Reforma Administrativa. Revista de Direito Administrativo 217/94.

55 Vide nesse sentido, BARBOSA, Joaquim Simões e SOUZA, Carlos Affonso Pereira de. Arbitragem nos Contratos Administrativos: Panorama de uma Discussão a ser Resolvida. In: Arbitragem Interna e Internacional (Questões de Doutrina e da Prática). ALMEIDA, Ricardo Ramalho (Coord.), Rio de Janeiro: Renovar, 2003, p. 283. 
Todavia, Luís Roberto Barroso registra que "a maioria dos autores tem manifestado o entendimento de que enquanto não editado o estatuto jurídico a que se refere o $\$ I^{\circ}$, do art. 173, continua a aplicar-se a Lei $n^{\circ} 8.666 / 93$, diploma legal pré-existente e único para todos os entes da Administração". ${ }^{56}$ Corroborando esse entendimento, destacamos posição de Celso Antônio Bandeira de Mello:

"Destarte, cumpre afirmar a conclusão de que as empresas estatais prestadoras de serviço público também se sujeitam às normas gerais de licitação e contratos expedidas pela Uniāo e, pois, que continuam e continuarão a ser regidas pela Lei $n^{\circ} 8.666$, de 21.6.93, com as suas alterações posteriores. Já as empresas estatais exploradoras de atividade econômica futuramente terão suas licitações e contratos regidos pela lei a que se refere o art. 22, XXVII, da Constituição Federal, com a redação que lhe deu o Emendão, isto é, na conformidade do Estatuto para elas previsto no art. 173 da Lei Magna. Enquanto isto não ocorrer persistirão regidas pela Lei $n^{\circ} 8.666$, com as ressalvas inicialmente feitas." 57

Ressalte-se que mesmo nos casos das empresas estatais exploradoras de atividade econômica, o regime de direito privado deverá conviver limitado pelas imposições do direito público, sujeitando-se, portanto, aos seus princípios, como por exemplo, o da legalidade. Dessa forma, mesmo que houvesse a possibilidade de utilização da arbitragem, em razão do regime jurídico de direito privado e por estar afastada a incidência do $\S 2^{\circ}$, do art. 55 , da Lei $n^{\circ} 8.666 / 93$, ainda assim haveria a necessidade de que a lei a ser criada prevendo o estatuto jurídico dessas empresas fizesse expressa referência à possibilidade de utilização da arbitragem.

Com relação às empresas estatais prestadoras de serviço público, não há grande discussão, pois a maior parte da doutrina entende que o art. $23, \mathrm{XV}$, da Lei $\mathrm{n}^{\circ} 8.987 / 95$ contemplou a arbitragem como cláusula essencial do contrato de concessão (não obstante a imprecisão terminológica da expressão "modo amigável para de solução das divergências contratuais", conforme mencionado supra). Está, portanto, respeitado o princípio da legalidade como pressuposto da arbitrabilidade subjetiva. A problemática está certamente no campo da arbitrabilidade objetiva, eis que esses contratos são regidos pelo Direito Administrativo, conforme registra Adilson Abreu Dallari em estudo sobre o tema:

"Saliente-se, entretanto, que o problema não é o de falta de base legal, tanto porque, isso já existe, quanto porque, se não existisse, poderia ser

56 BARROSO, Luís Roberto. Sociedade de Economia Mista Prestadora de Serviço Público. Cláusula Arbitral Inserida em Contrato Administrativo sem Prévia Autorização Legal. Invalidade. In: Temas de Direito Constitucional, Tomo II, Rio de Janeiro: Renovar, 2003, p. 604.

57 MELLO, Celso Antônio Bandeira de. Licitação nas Estatais em Face da EC $n^{\circ} 19$. Boletim de Licitações e Contratos 12/ 585-586. Essa é também a pusição de Maria Sylvia Zanella Di Pietro (Empresa Subsidiária de Sociedade de Economia Mista. Submissão à Lei $n^{\circ}$ 8.666. In: Temas Polêmicos sobre Licitações e Contratos, São Paulo: Malheiros, $4^{\mathrm{a}}$ ed., 1999, p. 28). 
instituida por lei ordinária federal, estadual ou municipal. (...) Argumentam alguns que, diante dos princípios da supremacia do interesse público, da indisponibilidade dos interesses públicos e da indisponibilidade dos instrumentos destinados à defesa dos interesses públicos, a Administração Pública ao contratar não poderia abrir mão da possibilidade de recorrer ao Poder Judiciário." 58

Dallari conclui que nada disso impede a adoção da arbitragem, pois ao optar pela arbitragem o contratante público não está transigindo com o interesse público nem abrindo mão de instrumentos de defesa de interesses públicos. Ao contrário, está escolhendo uma forma mais expedita ou um meio mais hábil para a defesa do interesse público. ${ }^{59}$

Selma Lemes, ao tratar da arbitragem na concessão de serviço público, reconhece que o eixo da discussão muda de posição quando passamos a tratar a questão sob o prisma do direito administrativo e afirma serem suscetíveis de solução arbitral apenas as questões que não dizem respeito às atribuições de jure imperii, nem de direito, mas somente as questões de fato e puramente patrimoniais, sendo necessário efetuar a distinção entre "atos administrativos de autoridades" e "atos de simples gestão" (gestão patrimonial). ${ }^{60}$

\section{VII - Posição da jurisprudência}

No âmbito da instância administrativa, diversas decisões foram proferidas pelo Tribunal de Contas da União analisando a possibilidade de entes da Administração

58 DALLARI, Adilson Abreu. Arbitragem na Concessão de Serviço Público. Revista de Informação Legislativa 128/63-67, p. 66.

59 Idem.

60 LEMES, Selma M. Ferreira. A Arbitragem e os Novos Rumos Empreendidos na Administração Pública: A Empresa Estatal, o Estado e a Concessão de Serviço Público. In: Aspectos Fundamentais da Lei de Arbitragem, MARTINS, Pedro Batista, LEMES, Selma M. Ferreira e CARMONA, Carlos Alberto, Rio de Janeiro: Forense, 1999, pp. 193-194. Em estudo mais recente sobre o tema, Selma Lemes conclui que:"(...) os contratos de concessão de serviços públicos não apenas podem estabelecer a solução de controvérsias por arbitragem, como devem assim proceder. $O$ Edital e o contrato de concessão ao obrigatoriamente disporem nas denominadas cláusulas essenciais sobre a negociação, conciliação, mediação e arbitragem, poderiam, por exemplo, estabelecer que as divergências referentes às compensações ou indenizações decorrentes das modificaçōes dos serviços contratados, por razões de interesse público, atrasos imputáveis ao concedente durante o período da construção etc; enfim, as controvérsias surgidas quanto à interpretação ou aplicação do contrato e que representassem ônus ao concessionário seriam submetidas a uma Comissão de Conciliação e Arbitragem. que observaria um regulantento próprio disposto previamente pelo poder concedente, fundamentando-se nos princípios presentes na conciliação e na arbitragem, que prevêem a igualdade de tratamento das partes, o direito ao contraditório e a independência $e$ imparcialidade dos árbitros e conciliadores. "(Arbitragem na Concessão de Serviços Públicos Arbitrabilidade Objetiva. Confidencialidade ou Publicidade Processual? Palestra proferida na reunião do Comitê Brasileiro de arbitragem - CBAR realizada em São Paulo em 06.05.03. conforme disponibilizado pela Escola de Direito de São Paulo da Fundação Getúlio Vargas (FGVEDESP/ FGV Law), p. 15). 
Pública se submeterem à arbitragem. Essas decisões não apresentam uniformidade de fundamentação, mas, em regra, tem-se decidido no sentido de não ser possível a arbitragem sem lei expressamente autorizando, em clara referência ao princípio da legalidade. ${ }^{61}$

$\mathrm{Na}$ esfera judicial vem crescendo o número de decisões que tratam da possibilidade de entes da Administração Pública se submeterem à arbitragem. Essas decisões denotam a incerteza jurídica que ainda existe no Direito Brasileiro sobre a matéria, que acaba na maioria das vezes sendo levada à interpretação dos tribunais estatais.

Em primeiro lugar deve ser citado o famoso caso da Organização Lage ${ }^{62}$, já tantas vezes mencionado por todos os autores que trataram da questão. Trata-se de ação ajuizada pelos espólios de Henrique Lage e de Renaud Lage com a finalidade de receber indenização fixada por juízo arbitral, em razão da incorporação pela União ao patrimônio nacional dos bens e direitos das empresas da chamada Organização Lage e do Espólio de Henrique Lage, sob fundamento da existência de estado de guerra.

Em razão da dificuldade de se chegar a um acordo com relação ao valor da indenização, foi expedido o Decreto-lei $n^{\circ} 9.521$ de 1946, prevendo, dentre outras questões, que o quantum da indenização seria fixado por juízo arbitral. Previa, ainda, o referido Decreto-lei que o juízo arbitral deveria decidir a questão em única instância e sem recurso, sendo que a sentença arbitral seria final e definitiva, executável independentemente de homologação.

O juízo arbitral, constituído por Raul Gomes de Matos (indicado pela União), Antônio Sampaio Dória (indicado pelo espólio) e pelo Ministro aposentado do STF Manoel da Costa Manso, proferiu laudo fixando indenização, tendo a União tomado as medidas administrativas necessárias ao pagamento. Entretanto, em razão de mudança de governo, o pagamento não chegou a ser realizado em virtude de parecer do então Procurador-Geral da Fazenda alegando que a instituição do juízo arbitral era inconstitucional, pois constituía tribunal de exceção, o que era vedado pela Constituição de 1946.

A questão foi levada ao Poder Judiciário pelos espólios de Henrique e Renaud Lage, como mencionado acima. Em primeira instância a pretensão foi acolhida, determinando-se o pagamento da indenização fixada no juízo arbitral. No Tribunal Federal de Recursos, a questão foi amplamente examinada pelo Ministro Godoy Ilha, o qual, citando parecer de Castro Nunes juntado aos autos, defende a constituciona. lidade do juízo arbitral e a possibilidade de o Estado se submeter à arbitragem, entretanto, com a ressalva das relações em que age como Poder Público, conforme se verifica do trecho do acórdão transcrito abaixo:

61 As decisões proferidas pelo TCU foram amplamente analisadas por Jacob Dolinger e Carmen Tiburcio. Os autores tratam também da evoluçāo da jurisprudência arbitral e da jurisprudência estatal estrangeira e nacional sobre o tema. (Arbitragem Envolvendo o Estado e Entes da Administração Pública. In: Direito Internacional Privado - Parte Especial: Arbitragem Comercial Internacional, Rio de Janeiro: Renovar, 2003).

62 Agravo de Instrumento $n^{\circ} 52.181$ - GB, Relator Min. Bilac Pinto, RTJ 68/382-397. 
"Ao tempo do Império, assinala o parecer, muitas controvérsias se levantaram contra a possibilidade da extensão do instituto (...) às causas da Fazenda Nacional, prevalecendo, no sentido afirmativo, os autorizados pronunciamentos, dentre outros, de Lafayette, Visconde de Ouro Preto e do Conselheiro Silva Costa. E acrescenta não ser possivel a interdição do Juizo Arbitral, mesmo nas causas contra a Fazenda, o que importaria numa restrição à autonomia contratual do Estado que, como toda pessoa sui juris, pode prevenir o litígio pela via transacional, não se the podendo recusar esses direito, pelo menos na sua relação contratual ou privada, que só estas podem comportar solução pela via arbitral, 'dela excluidas aquelas em que o Estado age como Poder Público que não podem ser objeto de transação'. A hipótese para a qual se instituiu o Juízo Arbitral pelo Dl. 9.521 entra na primeira categoria." ${ }^{63}$ (grifo acrescentado)

O Supremo Tribunal Federal confirmou a decisão apoiando-se inteiramente no acórdão do Tribunal Federal de Recursos.

Cabe aqui tecer alguns comentários a essa decisão. Pelo trecho do acórdão transcrito acima, verifica-se que o entendimento que prevaleceu foi no sentido da possibilidade de o Estado se submeter à arbitragem, salvo quando age como Poder Público, e que o caso em análise tratava-se de uma relação de natureza privada do Estado. Ora, não nos parece que a incorporação de bens em decorrência do estado de guerra possa ser tratada como relação de natureza privada, uma vez que só ao Estado, investido do ius imperii, é dado o poder de interferir no patrimônio das pessoas, suprimindo-lhes o direito de propriedade. Além disso, em razão de ter sido a arbitragem instaurada por determinação do Decreto-lei $n^{\circ} 9.521 / 46$, não houve qualquer discussão relativa à necessidade de observância do princípio da legalidade. Por fim, reconheceu-se a natureza consensual do juízo arbitral, decisão que contraria a tendência atual de se conferir natureza jurisdicional ao instituto.

Observe-se que posteriormente, em 1989, o Tribunal Federal de Recursos voltou a apreciar a validade do juízo arbitral em contratos da Administração na Apelação Cível $n^{\circ} 137.279-D^{64}$, dessa vez fazendo menção expressa ao princípio da legalidade, conforme se observa do trecho da ementa transcrito abaixo:

"Sem autorização legislativa, não pode a autarquia celebrar compromisso para resolução de pendências por meio de juizo arbitral. Inadmissivel, no caso, o laudo arbitral, mantém-se a sentença que indeferiu a respectiva homologação." 65

Cumpre mencionar a decisão do Tribunal de Justiça do Distrito Federal, em agosto de 1999, no Mandado de Segurança impetrado por Seveng Civilsan S/A -

63 Idem, p. 391.

64 Sessão de 28.03.89. acórdäo publicado no DJ de 26.06.89.

65 Acórdão citado pelo Tribunal de Contas da União em decisão publicada na Revista de Direito Administrativo 193/ 341-351. 
Empresas Associadas de Engenharia e Construtora Andrade Gutierrez S/A contra ato do Tribunal de Contas do Distrito Federal, que determinava que a Companhia de Água e Esgotos de Brasília - Caesb se abstivesse de recorrer ao juízo arbitral. ${ }^{66}$ Note-se que a previsão de solução das controvérsias por juízo arbitral estava prevista no Edital de Licitação.

O Tribunal seguiu unanimemente o voto da Desembargadora Relatora Nancy Andrighi, que decidiu pela concessão da segurança, determinando o cumprimento do Edital, ou seja, que as controvérsias entre os impetrantes e a Caesb fossem resolvidas por arbitragem. Em seu voto, a Desembargadora entendeu que, como os contratos haviam sido celebrados durante a vigência do Decreto-lei $n^{\circ} 2.300 / 86$, e que a vedação para constituir-se juízo arbitral prevista no parágrafo único do art. 45 desse diploma se restringia aos contratos celebrados com pessoas físicas ou jurídicas domiciliadas no estrangeiro, não alcançando, desta forma, os contratos firmados com pessoas físicas ou jurídicas com domicílio no País (hipótese do caso em análise), não havia qualquer vedação à previsão da arbitragem no instrumento licitatório. Além disso, a arbitragem estaria permitida, pois tratava-se de concorrência internacional com financiamento concedido por organismo internacional, devendo-se aplicar o art. 25, \& 13, do mesmo Decreto-lei. Defendeu, ainda, a relatora, que a possibilidade de discordâncias contratuais serem discutidas por juízo arbitral não afeta a indisponibilidade do interesse público e que a possibilidade da adoção da arbitragem nos contratos administrativos está consubstanciada no art. 54 da Lei $n^{\circ}$ 8.666. Vale transcrever alguns trechos da decisão:

"Como se pode notar, a vedação estipulada para constituir-se juízo arbitral para dirimir questões alusivas aos contratos se restringia àqueles celebrados com pessoas fisicas ou jurídicas domiciliadas no estrangeiro, näo alcançando, desta forma, os contratos firmados com pessoas físicas ou juridicas com domicílio no País.

Os contratos, ora em análise, foram firmados com pessoas jurídicas com domicílio no Brasil; referem-se à concorrência internacional objetivando a aquisição de bens ou serviços, inclusive parte do pagamento é feito com o produto do financiamento concedido por organismo internacional, de que o Brasil faz parte, no caso o Bird.

Assim, não havia, na ocasião do procedimento licitatório, qualquer vedação ao socorro do juizo arbitral para solucionar questōes contratuais. (...)

É notória a indisponibilidade do interesse público. E a possibilidade de questões ou discordâncias contratuais, que não possam ser solucionadas amigavelmente, serem discutidas por juízo arbitral não afeta dita indisponibilidade. (...)

66 MS 1998002003066-9 - Conselho Especial - TJDF - j. 18.05.199, Rela. Des ${ }^{\mathbf{2} . ~ N a n c y ~}$ Andrighi. Vide comentário à decisão feito por Clávio Valença Filho (Arbitragem e Contratos Administrativos. Revista de Direito Bancário do Mercado de Capitais e da Arbitragem 9/ 358-373). 
Acrescente-se que, pelo art. 54, da Lei 8.666/93, os contratos administrativos regem-se pelas suas cláusulas e preceitos de direito público, aplicando-selhes supletivamente os princípios da teoria geral dos contratos e as disposições de direito privado, o que vem a reforçar a possibilidade de adoção do juízo arbitral para dirimir questões contratuais." 67

Cabe apenas uma observação com relação à interpretação conferida ao parágrafo único do art. 45 do Decreto-lei $n^{\circ} 2.300$. Conforme explicitado supra, entendemos que este dispositivo tacitamente veda a utilização da arbitragem nos contratos celebrados pela União ou suas autarquias com pessoas físicas ou jurídicas domiciliadas no estrangeiro, não podendo ser interpretado a contrario sensu, para permitir a utilização da arbitragem nos contratos celebrados com pessoas jurídicas domiciliadas no Brasil. Não faria sentido o legislador vedar a adoção da arbitragem para os contratos celebrados com sociedades estrangeiras - onde com mais razão se justificaria a sua adoção - e permitir a sua utilização nos contratos com sociedades brasileiras. Nesse sentido, a Lei $n^{\circ} 8.666$ trouxe redação mais precisa com a expressão "inclusive aquelas domiciliadas no estrangeiro", deixando claro que o dispositivo também se aplica aos contratos celebrados com pessoas físicas ou jurídicas nacionais.

Em janeiro de 2002, o juiz da $2^{a}$ Vara de Fazenda Pública de Porto Alegre/RS julgou pedido de liminar requerido pela Comercializadora Brasileira de Energia Emergencial (CBEE) (autora), visando à expedição de ordem para suspender a instituição de juízo arbitral instaurado pela parte ré perante a Câmara de Comércio Internacional $(\mathrm{CCI})$. O magistrado considerou inválida a instauração da arbitragem fora do Brasil, pois, como havia no contrato celebrado entre as partes cláusula compromissória prevendo que a sede da arbitragem seria na cidade de Porto Alegre, o juízo arbitral só poderia se dar nos limites do território nacional. Além disso, o juiz afirmou que a arbitragem não afasta a tutela jurisdicional, o que inclusive, está expresso no contrato, e prevê a aplicação da Lei $n^{\circ} 8.666$ à CBEE, por se tratar de sociedade de economia mista, conforme trecho da decisão transcrito abaixo:

"Não fosse só tal aspecto tão flagrante, há ainda que, conforme sustenta a parte autora, 'a arbitragem não afasta a tutela jurisdicional - como não poderia deixar de ser - que pode, inclusive, como prevê o contrato' (Cláusula Trigésima Sexta), questionar o próprio juízo arbitral, que é o objeto da presente demanda, na sua expressão de lide parcial, mais especificamente com a questão da ampla defesa e o contraditório, garantias constitucionais arranhadas na medida em que, além de outros aspectos, o material da arbitragem não foi vertido para o vernáculo, impondo tradução por intérprete juramentado, que, 'em se tratando de sociedade de economia mista, está sujeita às normas da Lei 8.666/93', exigentes de prazo incompativeis com o prazo de trinta dias para indicação do árbitro pela CBEE." 68 (grifo acrescentado) 
A decisão do magistrado é no sentido de: (i) concessão da liminar para determinar a suspensão da instituição do juízo arbitral instaurado pela parte ré, devendo esta se abster de praticar qualquer ato tendente a institui-lo ou nele prosseguir, sob pena de multa diária; (ii) comunicação à CCI — via carta rogatória - da existência de duas demandas em curso no Brasil questionando parte dos fatos versados no juízo arbitral (litispendência), da discussão da validade da cláusula compromissória, da determinação judicial da parte ré em se abster de qualquer ato ou manifestação tendente a instituir ou prosseguir com o procedimento arbitral, bem como requerendo a suspensão do juizo arbitral nos termos do art. 25 da Lei $n^{\circ} 9.307 / 96{ }^{69}$

Concordamos com o magistrado no sentido da necessidade de observância da sede da arbitragem na cidade de Porto Alegre, nos termos do que havia sido pactuado pelas partes na cláusula arbitral. Todavia, não fica claro na leitura da decisão se a sede do tribunal arbitral já havia sido fixada e se estava localizada em Paris. Resta a dúvida, portanto, se houve confusão entre a sede da CCI, que fica em Paris, e a sede da arbitragem. ${ }^{70}$ Ressalte-se ainda que o magistrado fez menção à aplicação da Lei ${ }^{\circ} 8.666 / 93$ à CBEE, em razão de sua condição de empresa pública, mas não se referiu ao art. $55, \S 2^{\circ}$ da Lei. Por fim, não concordamos com a ordem dada pelo magistrado à CCI para suspensão do juízo arbitral, pois caberia tão-somente notificar a CCI da sua decisão, mas nunca proferir ordem para que a corte de arbitragem suspenda o processo arbitral.

Essa decisão foi confirmada pelo Tribunal de Justiça do Rio Grande do Sul, que, entretanto, abordou outro aspecto do caso. Como a cláusula compromissória no contrato original determinava que as controvérsias seriam dirimidas pelas partes $\mathrm{e}$, caso não houvesse consenso, poderia ser instaurado um juízo arbitral, o Tribunal não considerou essa cláusula obrigatória para as partes. ${ }^{71}$

Por fim, cite-se a liminar concedida em junho de 2003 por juíza da $3^{a}$ Vara de Fazenda Pública do Estado do Paraná no âmbito da ação proposta pela Companhia Paranaense de Energia - COPEL contra a UEG Araucária Ltda., visando à declaração de nulidade da cláusula compromissória constante do contrato celebrado entre essas duas empresas. A COPEL fundamentou seu pedido na existência de direitos indisponíveis no contrato e na ausência de requisitos legais para a instituição de uma

68 AC 00109052374, 2 Vara de Fazenda Pública de Porto Alegre/RS, j. 12.01.02, Juiz Cláudio Luís Martinewski, Revista de Direito Bancário, do Mercado de Capitais e da Arbitragem 18/390391.

69 Idem, pp. 390-391.

70 Confira-se esse trecho da decisão: "Ocorre que a parte ré, no curso das tais demandas, mais precisamente em 18.12.2001, notificou a parte autora que havia requerido a instauração do juizo arbitral, de acordo com as regras da Câmara de Comércio Internacional, com indicação do árbitro Donald Francis Donovan, 'tendo a parte autora recebido correspondência pela qual foi confirmado $o$ inicio do processo de instauraçāo junto a International Chamber of Commerce, com sede em Paris.." (grifo acrescentado). Idem, p. 390.

71 DOLINGER, Jacob e TIBURCIO, Carmen. Arbitragem Envolvendo o Estado e Entes da Administração Pública. In: Direito Internacional Privado - Parte Especial: Arbitragem Comercial Internacional, Rio de Janeiro: Renovar, 2003. 
arbitragem válida. A COPEL requereu a antecipação de tutela para o fim de suspender a eficácia da cláusula arbitral, bem como a concessão de liminar para que a UEG se abstivesse de praticar atos relacionados à continuidade do processo arbitral já instaurado. A juíza concedeu a liminar, entendendo estarem presentes os requisitos para a concessão da medida e ordenou que fosse dada ciência da decisão à $\mathrm{CCI}$ :

"No caso em exame, não há como ser negado, a princípio, a existência de interesse público no contrato firmado entre as partes, notadamente por estar a Autora obrigada, na hipótese de inadimplemento, a adquirir a Usina, independentemente da conveniência. Por conseguinte, resta demonstrado o 'fumus boni iuris'.

O perigo na demora é inconteste, pois a Autora já foi notificada para apresentar defesa perante a CCI, sendo que para tanto deverá adiantar as despesas de elevado valor, inclusive para o pagamento dos honorários do árbitro. "72

Note-se que, diversamente da decisão anterior, nenhuma ordem foi dada para a Corte de Arbitragem da CCI, limitando-se a juíza a ordenar que fosse dada ciência de sua decisão à CCI.

A UEG interpôs agravo de instrumento dessa decisão, alegando a validade da cláusula arbitral e que somente ao árbitro caberia decidir sobre a sua própria competência. Alegou, ainda, a desnecessidade de autorização legislativa e que o contrato havia sido celebrado em condições de igualdade, regendo-se pelo direito privado. $\mathrm{O}$ Desembargador Relator decidiu pela manutenção da decisão recorrida, negando efeito suspensivo ao agravo, por entender que a reforma da decisão agravada implicaria em ônus mais grave à recorrida, uma vez que já havia sido iniciado o processo arbitral na França. O Desembargador registrou que a eventual procedência da demanda importaria na nulidade da sentença arbitral, nos termos do art. 32, I, da Lei $n^{\circ}$ 9.307/96 (hipótese de nulidade do compromisso). Por fim, o Relator afirmou que, por se tratar de empresa pública prestadora de serviço público, deveriam ser observadas as normas de direito público e que havia a possibilidade de envolvimento de bens públicos, além da aparente vedação prevista no art. 55 , $\S 2^{\circ}$, da Lei $n^{\circ} 8.666 / 93 .{ }^{73}$ Há que se esperar ainda a decisão de mérito. ${ }^{74}$

\section{VIII - Conclusão}

No tocante à arbitrabilidade subjetiva, verificamos que o princípio da legalidade constitui um pressuposto necessário à utilização da arbitragem pelo Estado e entes

72 Decisão da juíza Josely Dittrich Ribas da $3^{a}$ Vara de Fazenda Pública do Pública do Estado do Paraná proferida em 3.06.03.

73 Voto do Desembargador Relator Leonardo Lustosa proferida em 26.06.03.

74 Vide comentário a essa decisão feito por Selma Lemes em artigo publicado no Valor Econômico em 19.08.03. 
da Administração Pública. Em razão desse princípio, a Administração, além de só poder fazer aquilo que não é vedado por lei, também só pode fazer o é expressamente permitido por lei. Ou seja, não basta não haver lei impedindo, deve haver lei expressamente autorizando a prática da arbitragem.

Ao analisarmos a legislação nacional de Direito Administrativo, constatamos que o art. $55, \S 2^{\circ}$, da Lei $n^{\circ} 8.666 / 93$, constitui sério obstáculo à utilização da arbitragem nos contratos celebrados pela Administração Pública no âmbito dessa lei e não concordamos com aqueles que vêem no art. 54 uma autorização à utilização da arbitragem. Verificamos, ainda, que a matéria vem evoluindo na legislação nacional e já há hipóteses específicas que autorizam a arbitragem, tais como o art. 23, XV, da Lei de Concessões (Lei $n^{\circ}$ 8.987/95), art. 93, XV, da Lei Geral de Telecomunicações (Lei ${ }^{\circ}$ 9.472/97), art. 43, X, da Lei do Petróleo (Lei $n^{\circ}$ 9.478/97) e 0 art. $2^{\circ}$ da Lei do MAE (Lei $n^{\circ} 10.433 / 02$ ). Indaga-se se essas leis, em razão de tratarem de atividades específicas, já estariam tornando a matéria arbitrável, e, portanto, suprindo os requisitos da arbitrabilidade subjetiva e objetiva de uma só vez.

No que se refere à arbitrabilidade objetiva, não é pacífica a natureza dos direitos envolvidos nos contratos celebrados pela Administração Pública. Todavia, a maioria da doutrina admite a existência de contratos celebrados pela Administração envolvendo direito patrimoniais disponíveis, defendendo-se a utilização da arbitragem nesses casos, em conformidade com o escopo determinado pelo art. $1^{\circ}$ da Lei $n^{\circ}$ 9.307/96.

Quanto à possibilidade de as empresas públicas e sociedades de economia mista exploradoras de atividade econômica se valerem da arbitragem, a questão também não é pacífica na doutrina. É necessário que seja criada o mais rápido possível a lei que estabelecerá o estatuto jurídico dessas empresas, com expressa referência à possibilidade de utilização da arbitragem, para que se ponha fim à controvérsia. Também no âmbito das empresas estatais prestadoras de serviço público não está claro na doutrina se todas as cláusulas dos contratos de concessão poderão ser submetidas à arbitragem.

A falta de clareza da legislação, aliada à falta de uniformidade na doutrina, vêm levando o tema cada vez mais aos nossos tribunais, seja no âmbito administrativo, seja no âmbito judicial. Todavia, a jurisprudência ainda tem se mostrado confusa e não uniforme.

Por essas razões, acreditamos que seja fundamental a edição de lei que venha a estabelecer de modo claro e preciso a utilização do instituto da arbitragem pela Administração Pública, definindo os seus limites e particularidades, de modo a gerar segurança para aqueles que contratam com o Estado e pôr fim à controvérsia. 


\section{Dicionário de Tecnologia Jurídica}

Pedro Nunes

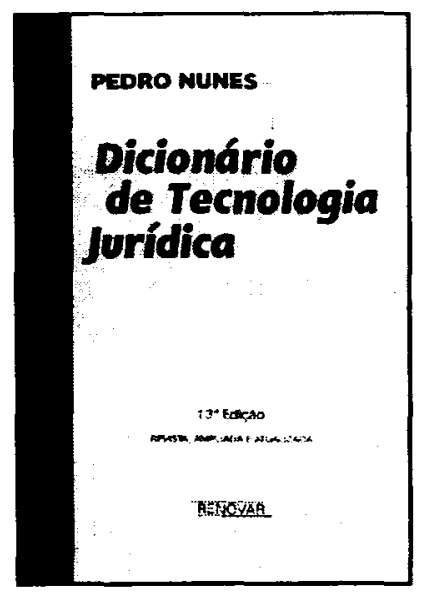

Esta obra representa um caminho de pesquisa seguro, para o estudante. $O$ Atualizador não olvidou o material existente, antes procurou seguir o mesmo modo didático de se tratar cada verbete. Com efeito, mesmo ampliada, esta nova edição segue o mesmo padrão de tratamento para cada instituto jurídico. Este é um livro que, muito embora seja direcionado para um público, é também encaminhado a todos aqueles que, eventualmente, se deparam com termos jurídicos não conhecidos.

Ref. 0223

Form. 16x23

Encadernado 1.198 págs. 1999 13- edição

\section{Direito Agrário}

Rafael Augusto de Mendonça Lima

O autor enfatiza aqui o Estatuto da Terra e leis complementares e exalta a importância do Direito Agrário no âmbito legislativo, na doutrina e no ensino jurídico. $O$ Direito Agrário tem princípios e institutos próprios, que servem como critérios para a elaboração das leis agrárias e para a sua interpretaçāo. Essa é a matéria tratada neste livro, atualizada de acordo com a Constituição Federal de 1988, a legislação ordinária e a doutrina.

Ref. 0076

Form. 14x21
Brochura

1997
512 págs. $2^{2}$ ed.
REAE AUGUSTO DE MFADONGA LIMA

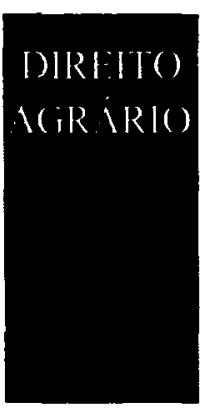

2* Eorcio 